\title{
A Case Study of a Community
Affected by the Witch and Guejito
Fires A Case Study of a Community
Affected by the Witch and Guejito
Fires A Case Study of a Community
Affected by the Witch and Guejito
Fires
}

Alexander Maranghides William Mell

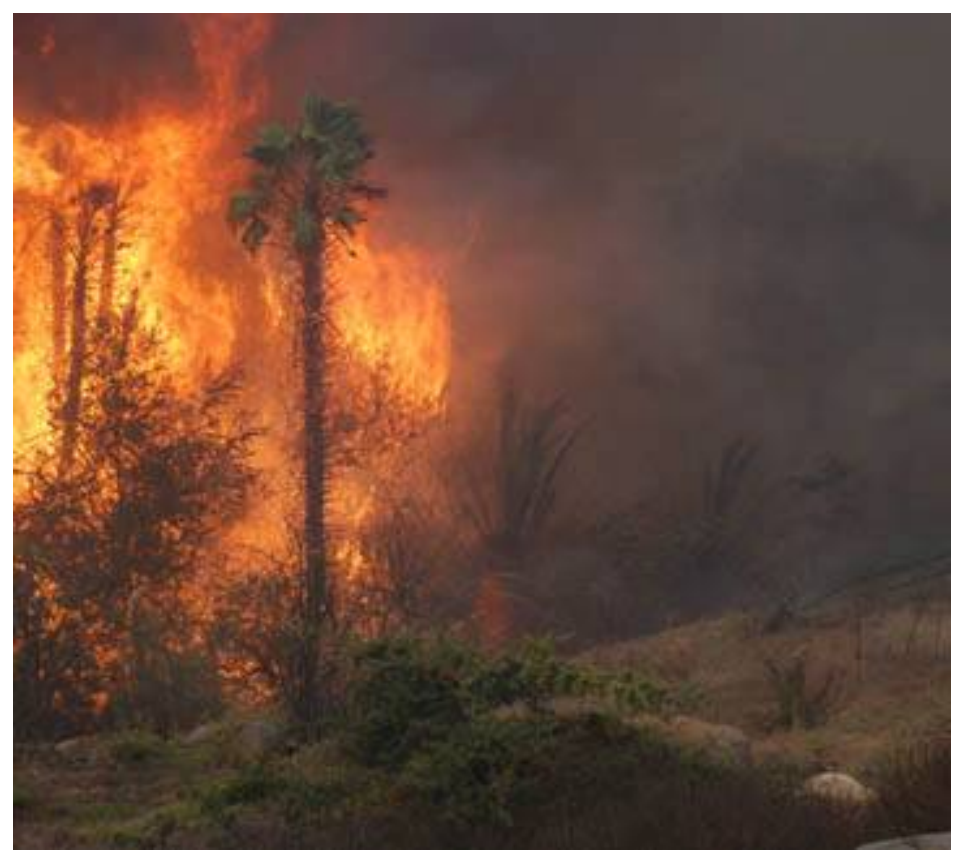




\title{
A Case Study of a Community Affected by the Witch and Guejito Fires
}

\author{
Alexander Maranghides \\ William Mell \\ U.S. Department of Commerce \\ Technology Administration \\ Building and Fire Research Laboratory \\ National Institute of Standards \\ And Technology \\ Gaithersburg, MD 20899
}

April 2009

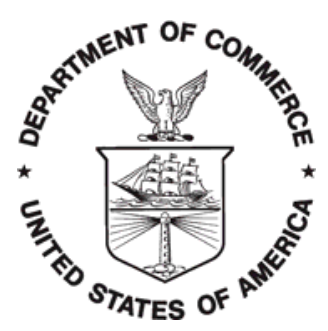

U.S. Department of Commerce

Gary Locke, Secretary

National Institute of Standards and Technology

Patrick D. Gallagher,Acting Director 
Certain commercial entities, equipment, or materials may be identified in this document in order to describe an experimental procedure or concept adequately. Such identification is not intended to imply recommendation or endorsement by the National Institute of Standards and Technology, nor is it intended to imply that the entities, materials, or equipment are necessarily the best available for the purpose.

National Institute of Standards and Technology Technical Note 1635 Natl. Inst. Stand. Technol. Technical Note 1635, 59 pages (June 2009) 


\section{Table of Contents}

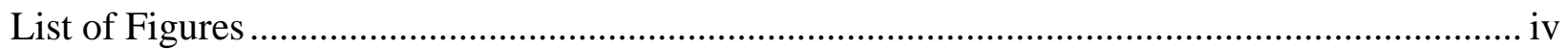

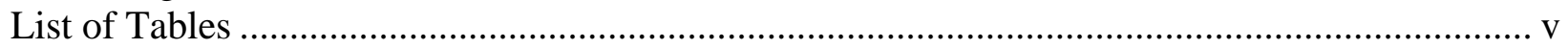

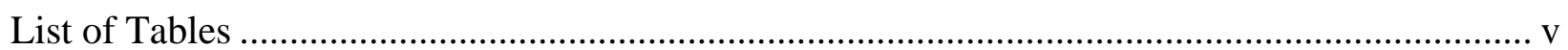

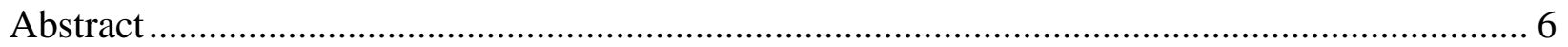

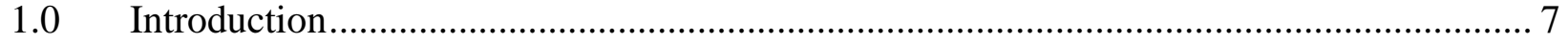

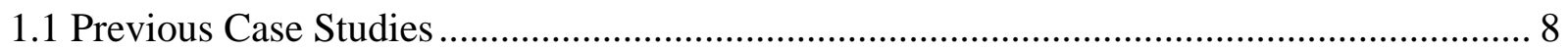

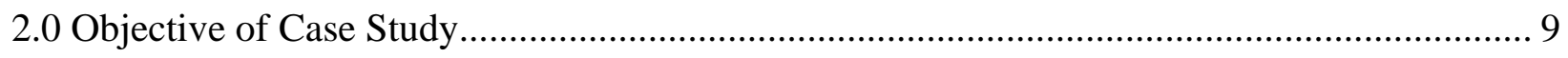

3.0 Area of interest - Rancho Bernardo, The Trails Community ..................................................... 9

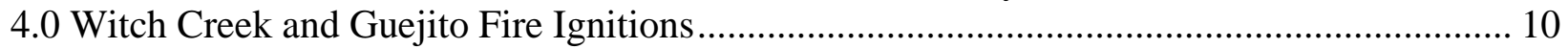

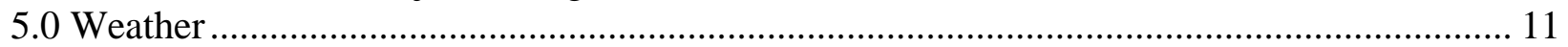

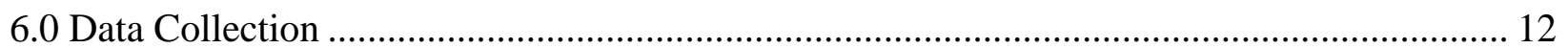

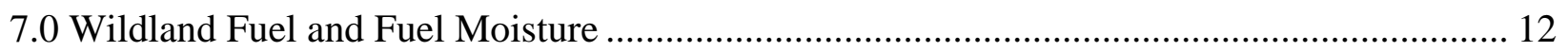

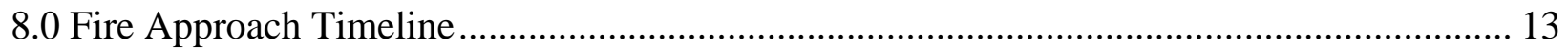

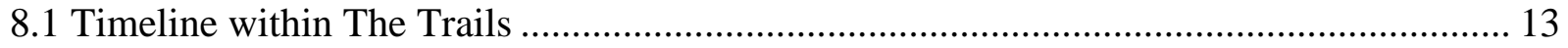

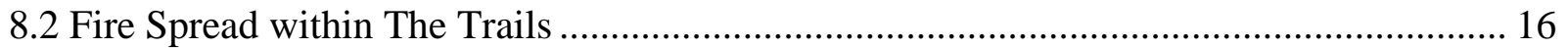

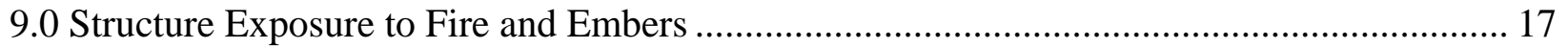

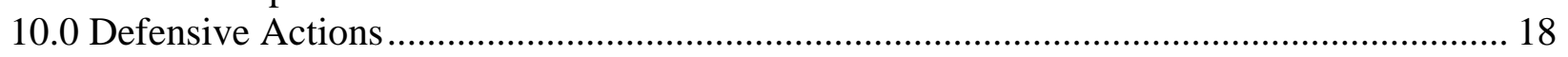

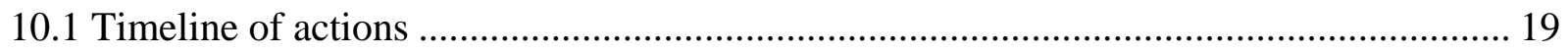

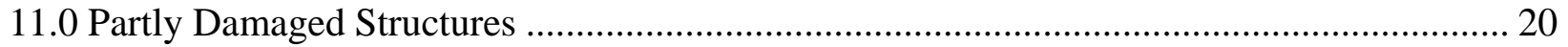

11.1 Interior versus Perimeter Structural losses .............................................................. 22

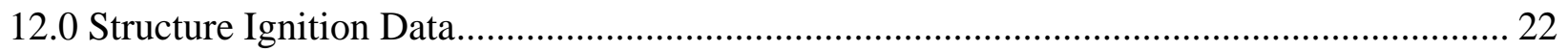

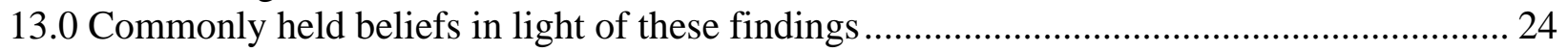

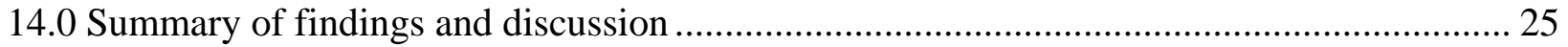

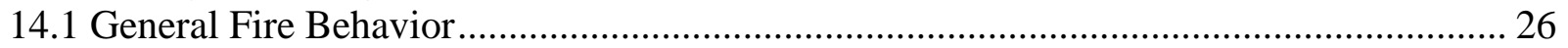

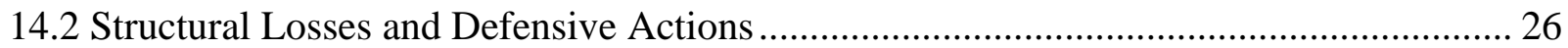

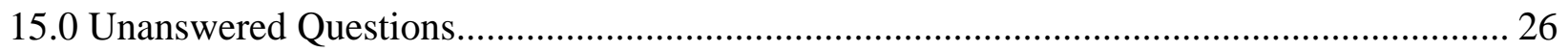

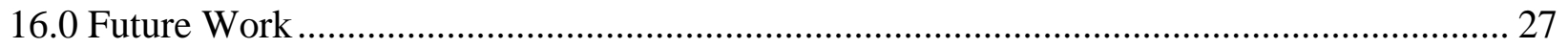

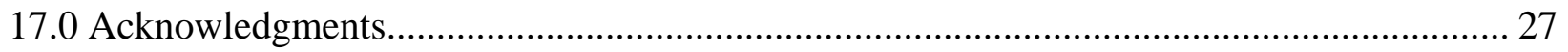

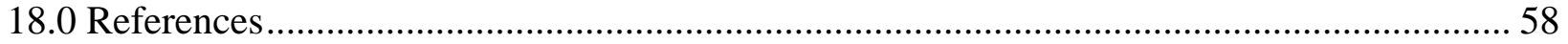




\section{List of Figures}

Figure 1: The Trails Community, Destroyed Homes (in Yellow) and Fire Perimeter after the Guejito and Witch Fires ....................................................................................... 29

Figure 2: Destroyed Structures in the vicinity of Rancho Bernardo, CA ................................. 30

Figure 3: Structure Densities in Three Different WUI Settings .............................................. 31

Figure 4: Origins of the Guejito and Witch Creek Fires, the combined perimeter of both fires and the locations of the weather_stations used later in the report. (map Courtesy of

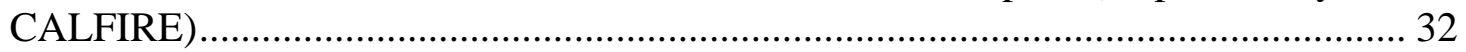

Figure 5: Weather data from Ramona Airport................................................................. 33

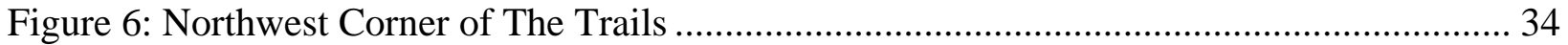

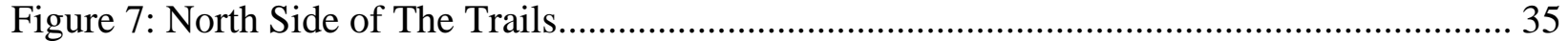

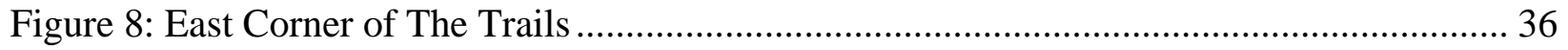

Figure 9: Southeast Corner of The Trails - Sycamore Creek .................................................. 37

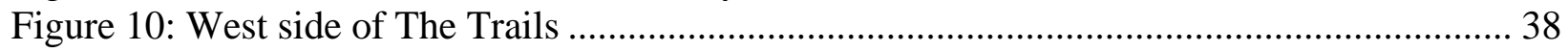

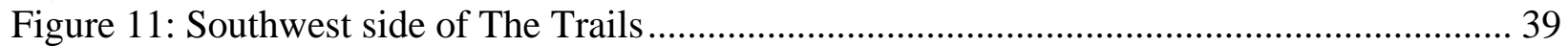

Figure 12: Angosto Way before October 22 $2^{\text {nd }}, 2007$ (circa 2005).......................................... 40

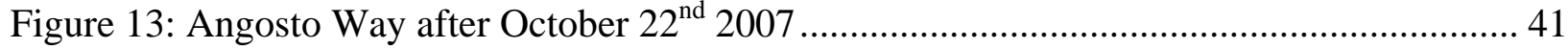

Figure 14: Topographic mps of The Trails .................................................................... 42

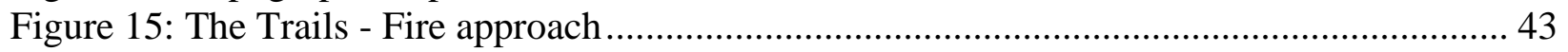

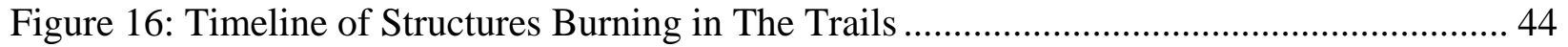

Figure 17: The Trails - Flame Spread and Needle Freeze .................................................... 46

Figure 19: Golf Ball Providing Direction of Highest Heat Flux ............................................ 47

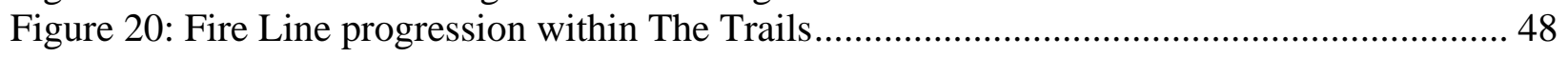

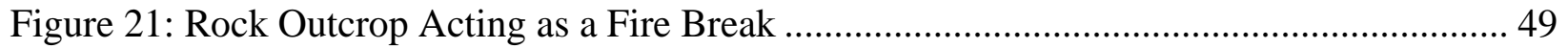

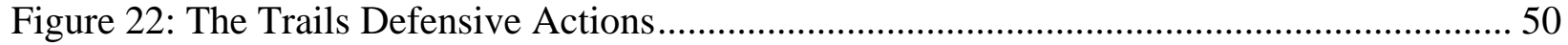

Figure 23: Impacts of the Defensive Actions Taken at The Trails .......................................... 51

Figure 24: Damaged Structures. See Table 6 for further information on each house according to number on figure.

Figure 25: The Trails - Ignition categories of destroyed structures and perimeter/interior outline

Figure 26: Structure Ignition Category A Fire from the wildlands burns uninterrupted up to the

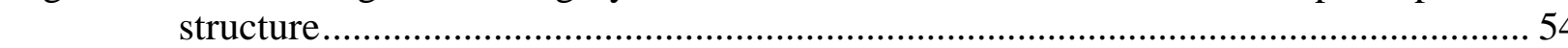

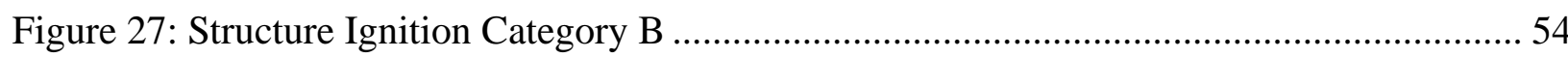

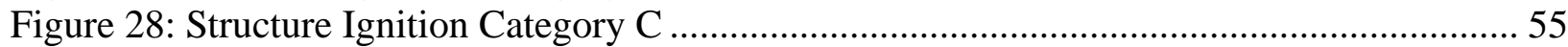

Figure 29: Potential Structure Ignition Categories A, B and C .......................................... 56

Figure 30: House burning times, fire spread and fire jumps ............................................. 57 


\section{List of Tables}

Table 1: Geographic Locations of Four Weather Stations ...................................................... 11

Table 2: Weather Summary ............................................................................................ 11

Table 3: Timeline of Completely Destroyed Structures ...................................................... 15

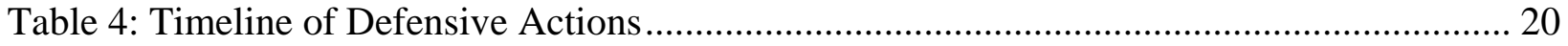

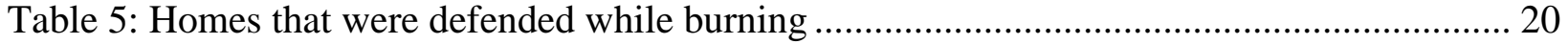

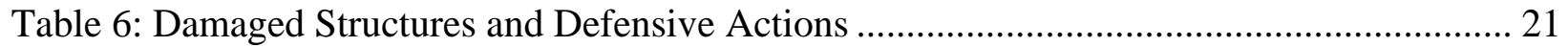

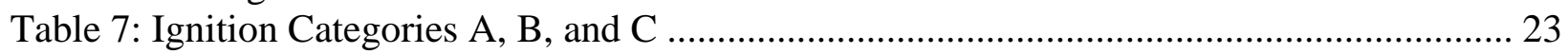

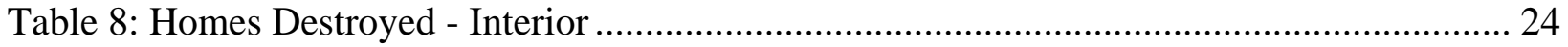

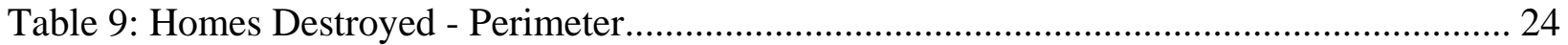

Table 10: Time Distribution of Potential Structure Ignition Categories A, B, and C ................. 24 


\title{
A Case Study of a Community Affected by the Witch and Guejito Fires
}

by

\author{
Alexander Maranghides, William Mell
}

\begin{abstract}
The National Institute of Standards and Technology (NIST) has a Reduced Risk of Fire Spread in Wildland-Urban Interface (WUI) Communities research program. The program objective is to develop, by the end of FY2013 first generation tools for improved risk assessment and risk mitigation in WUI (wildland-urban interface) communities at risk from wildfires. These tools will be developed and tested through a coordinated effort that includes laboratory and field measurements, physics-based fire behavior models, and economic cost analysis models. The NIST WUI Team was invited by CAL FIRE to collect post incident data from the California October 2007 fires. Early on, the NIST WUI Team initiated a case study within the Witch Fire perimeter. The case study is focused on The Trails development at Rancho Bernardo, north of the City of San Diego. There were 274 homes in The Trails, with 245 within the fire perimeter 74 homes were completely destroyed and 16 were partly damaged. Field measurements included structure particulars, specifically roof type, proximity of combustibles to the structure, and damage to wildland and residential vegetation. Documentation included over 11000 pictures. The data collected and the data analysis to be conducted are divided into three initial papers. This paper will address the event timeline reconstruction and general fire behavior observations. The second paper will investigate the impacts of structure attributes, landscaping characteristics, topographical features and wildland fire exposure on structure survivability. Lastly, the third paper will investigate the use computer modeling as a tool to understand fire behavior at the WUI.
\end{abstract}

KEY WORDS: Wildland Urban Interface, WUI, fire behavior, community, Witch fire, Guejito fire 


\subsection{Introduction}

The National Institute of Standards and Technology (NIST) has a Reduced Risk of Fire Spread in Wildland-Urban Interface (WUI) Communities research program. ${ }^{1}$ The program objective is to develop, by the end of 2013 first generation tools for improved risk assessment and risk mitigation in WUI communities at risk from wildfires. These tools will be developed and tested through a coordinated effort that includes laboratory and field measurements, physics-based fire behavior models, and economic cost analysis models.

Despite the increasing frequency and losses from WUI fires, there has been relatively little research, compared to fires within structures, on WUI fire spread. This is due, in part, to the fact that the subject of WUI fire research falls between traditional studies of building fires and forest fires, non-overlapping areas that in the past have been the responsibility of different branches of the government. Advances in measurement science are needed to effectively characterize and identify the conditions and mechanisms that result in a high risk of structure ignition across a range of WUI community types and conditions. Also, to date, no study that measures the effectivenes of current risk mitigation practices, whether through wildland fuel treatments or modification of residential fuels, has been conducted.

In this paper, the term WUI refers to locations where topographical features, vegetation types, local weather conditions and prevailing winds result in potential for ignition of structures from flames and embers of a wildland fire. ${ }^{2}$ The WUI fire problem is gaining momentum across the Southern continental US and is particularly severe across southern California. Between October 2003 and October 2007, seven California WUI fires destroyed a total of 8877 structures, $^{3}$ on average over 2200 structures per year. These seven fires resulted in 29 deaths, and over 317000 hectares (783 000 acres) burned. The 2003 Cedar fire and the 2007 California Firestorm are among the top four fire incidents for the number of structures destroyed and acres burned. The Witch fire, the largest of the fires that occurred during the 2007 California firestorm, burned 80124 hectares (197 990 acres) and destroyed 1125 residential structures, 509 outbuildings and 239 vehicles. Additionally, 77 residential structures and 25 outbuildings were damaged. Suppression costs were \$18 million. The property damages for the 2007 California Fire Storm, dominated by the Witch fire, are estimated at $\$ 1.8$ billion $^{4}$. The Witch Fire resulted in 45 firefighter injuries and two civilian fatalities. The Witch Fire started on October 21, 2007 at 12:35 pm at the Witch Creek area, east of Ramona in San Diego County.

The NIST WUI Team was invited by the California Department of Forestry and Fire Prevention (CAL FIRE) to collect post incident data from the California October 2007 fires. Early on, the NIST WUI Team initiated a case study within the Witch Fire perimeter. The case study is focused on The Trails development at Rancho Bernardo, $40 \mathrm{~km}$ (25 miles) north of the City of San Diego. There were 274 homes in The Trails, with 245 within the fire perimeter (Figure 1). Seventy four homes were completely destroyed and 16 were partly damaged.

The NIST data collection effort was designed to provide the necessary information to characterize the fire approach from the wildlands, the effects of fire within the community and the defensive actions taken. The intent has been to collect sufficient information, not only to characterize overall fire behavior in the WUI, but also to provide a foundation for future case studies. In that light, the following data collection methodology was developed and followed: 
1. Immediately after the fire, the construction characteristics of the destroyed residences were documented as well as all the damage to residential vegetation. This was necessary in order to capture the information before it was lost during community reclamation/ recovery efforts.

2. Characteristics of the wildlands surrounding the community were then documented and data were collected on the direction and intensity of the wildland fire approach.

3. Technical meetings were conducted with first responders to develop an event time line. At the same time, The Trails homeowners association provided critical input to the event timeline.

4. The community was revisited to collect structure construction and landscaping particulars on all non-destroyed structures.

The field data collection effort took approximately 1300 person hours over 14 months. Field data were collected by NIST personnel and CAL FIRE Fire Marshals with the support of residents, and the San Diego Fire and Police Departments. Field measurements included structure particulars, specifically roof type, proximity of combustibles to the structure, and damage to wildland and residential vegetation. Documentation included over 11000 digital photo images. The data collected and the data analysis conducted are divided into three initial papers. This paper will address primarily the event timeline construction and general fire behavior observations.

The second paper (work in progress) will explore the response of structures within The Trails to the WUI fire. Specifically, the second paper will “apply” different WUI hazard reduction guidelines to the community and determine how well the guidelines match the observed structure responses to the fire. The second paper will explicitly look at the structure construction and ornamental vegetation impact of structure survivability. A third paper will then be developed to compare the outputs of different fire models to the observed fire behavior and structural fire responses in the community. It is the intent of the authors to make the post-fire data set self-contained to enable its use by other fire researchers. The data set will be placed on the NIST WUI website at www.fire.nist.gov/wui.

The NIST WUI research effort has three components: computer model development, experiments and field data collection. All three components are interlinked and work together towards reducing losses in the WUI. Fire behavior models are being developed to help characterize and predict fire behavior in the wildlands and at the interface. At the same time, the experimental work is being conducted, with input from the field data collection, to characterize and quantify structure ignition vulnerabilities. Modeling and experiments will also be used to assess the potential effectiveness of hazard reduction techniques. By implementing this comprehensive methodological approach to studying communities burned by wildfires, the effectiveness and reliability of such techniques may be better assessed. ${ }^{5}$

\subsection{Previous Case Studies}

A number of studies have been conducted after WUI fires. Nonflammable roofs were defined in these cases as roofs made of non-combustible materials such as spanish type, cement, metal or asphalt shingle. In 1973, Howard ${ }^{6}$ observed a $95 \%$ survival of homes with nonflammable roofs. Foote $^{7}$ studied structural survival of the 1990 Paint fire and also observed over $80 \%$ survival of homes with nonflammable roofs and a clearance of $9 \mathrm{~m}$ (30 feet) or more. The 2007 USDA 
Angora fire study focused on assessing fuel treatments effects on fire behavior, suppression effectiveness and structure ignition. ${ }^{8}$ The report focuses on the wildland fuels treatments; however, it provided little information on structure characteristics. The Home Destruction Examination report of the Grass Valley Fire by Cohen and Stratton ${ }^{9}$ has provided a very useful time line reconstruction; however the report does not directly couple the defensive actions taken to the individual structures. More recently, the Institute for Business and Home Safety (IBHS) had conducted a study of the Witch Fire. ${ }^{10}$ The IBHS study's primary objective was to determine the relative merits of property protection measures ranging from individual actions to community-wide actions. Blanchi and Leonard ${ }^{11}$ conducted an investigation of structure ignition mechanisms after the 2003 fire in the Duffy community of Canberra, Australia 2003. The report identified that $50 \%$ of the ignitions were from embers only, $35 \%$ were from embers and radiant heat, while $10 \%$ were from radiant heat alone. The report also included the comprehensive survey form that was used in the data collection process. Although the survey has two questions relevant to defensive actions, very limited information on defensive actions taken is presented in the report.

The above listed case studies have in common the lack of linking defensive actions to individual structures. Without factoring in the defensive and suppression actions taken by first responders and homeowners, any conclusions on fire behavior and structure survivability are incomplete and may be erroneous.

\subsection{Objective of Case Study}

To understand the fundamentals of fire behavior at the WUI, the study attempts to address the following technical questions:

- How far within a community did the fire spread?

- To what extent did embers contribute to ignition of structures?

- Why did the fire spread stop when it did?

- $\quad$ Did all the structures ignite from the passage of the wildland fire front, or were some structures ignited later and why?

A timeline was developed for the event and the damage that occurred to structures, residential vegetation and surrounding wildland vegetation was documented. Additionally, the fire fighting and structure protection responses taken shortly before and during the fire event were also documented. An analysis of the resident evacuation was outside the scope of this study. An analysis of structure construction and landscaping particulars will be documented in the second paper (work in progress).

\subsection{Area of interest - Rancho Bernardo, The Trails Community}

This study is focused on The Trails community at Rancho Bernardo. The community extent is $1.5 \mathrm{~km}$ (1 mile) from East to West and $1 \mathrm{~km}(0.6 \mathrm{mile})$ from North to South. Community elevations range from $125 \mathrm{~m}$ to $200 \mathrm{~m}$ (415 feet to $660 \mathrm{feet}$ ) above sea level. The community rests on a knoll and is surrounded by valleys on three sides. To the north is Highland Valley, at elevations from $100 \mathrm{~m}$ to $110 \mathrm{~m}$ (330 feet to 365 feet). To the east is Sycamore Creek at similar elevations while to the west is a ravine at elevations ranging from $100 \mathrm{~m}$ to $135 \mathrm{~m}$ (330 feet to 
445 feet). The community is $23 \mathrm{~km}$ (14 miles) east of the Pacific Ocean. The community consists of 283 residential lots (Figures 1 and 2). Although some lots on the perimeter of the community are larger, typical lots are approximately $6000 \mathrm{~m}^{2}$ (1.5 acres). At the time of the fires there were 274 residences. Out of the 245 residences within the fire line, 74 were completely destroyed and an additional 16 sustained various degrees of damage. Housing density is approximately 116 homes per $\mathrm{km}^{2}$ (300 homes per square mile). Figure 3 illustrates three different housing densities. The Trails is represented on the left, a community in Rancho Santa $\mathrm{Fe}$, California is shown in the middle and a low density housing area is shown on the right. Note that the houses are not evenly distributed as the "density” becomes lower. The housing density within The Trails is greater than the densities seen outside of Rancho Bernardo but lower than the densities seen to the west of The Trails (Figure 2).

\subsection{Witch Creek and Guejito Fire Ignitions}

It was initially believed that The Trails community was impacted only by the Witch Creek Fire. The After Action Report October 2007 Wildfires, City of San Diego Response ${ }^{12}$ identified the Guejito Fire as the main fire that hit The Trails. The Witch Fire ${ }^{13}$ was ignited in the Witch Creek area east of Ramona, California, about $27 \mathrm{~km}$ (17 miles) east of The Trails, at approximately 12:35 pm on October 21, 2007. The cause of ignition was determined as electrical line arcing. The Guejito Fire ${ }^{\mathbf{1 4}}$ started, twelve and a half hours later, at 1:00 am October $22^{\text {nd }}, 2007$ at Guejito Creek drainage, on the South Side of California State Route 78 and $0.4 \mathrm{~km}$ (1/4 mile) west of Bandy Canyon Rd, or $10 \mathrm{~km}$ (6 miles) northeast of The Trails. The cause of ignition was identified as energized power lines contacted lashing wire. The following excerpt from the After Action Report described the general progression of the Guejito Fire:

“The Guejito Fire spread rapidly along the river bottom area of the San Pasqual Valley and southwest toward Highland Valley Road. SDFD strike teams engaged in numerous firefights along the Highland Valley Road and Bandy Canyon Road areas, but in many cases were forced to retreat by the wind-driven flames. It took just over two hours from the start of the Guejito Fire for the first homes in northeastern Rancho Bernardo to be destroyed by fire. The Guejito Fire spread west along Highland Valley Road, eventually spotting across Interstate 15 and ultimately destroying hundreds of structures in West Rancho Bernardo.”

Late Sunday night residents of Rancho Bernardo were informed through mass media that the Witch Fire would be arriving at their communities around 11:00 am Monday morning. The ignition of the Guejito Fire well to the west of the Witch Creek fire caused the anticipated timeline for resident evacuation to be moved into early Monday morning. By approximately 2:16 am (one hour and sixteen minutes after ignition, the Guejito Fire was identified as posing a significant threat to the Rancho Bernardo Community and the San Diego Fire Chief requested the activation of the City's Emergency Operation Center. Figure 4 contains a map illustrating the origins of the Guejito and Witch Creek Fires, the combined perimeter of both fires and the locations of the weather stations used later in the report. The combined perimeter encompasses the total area burned by both fires. 


\subsection{Weather}

Weather data was obtained from MESO West ${ }^{15}$ operated by the University of Utah. Four weather stations were used. The stations were selected for their proximity to either the study area or the fire origin. Table 1 lists the particulars of the stations. Figure 4 shows the geographical location of the stations, the fire origin locations for the Witch and Guejito fires, and the location of The Trails community.

Table 1: Geographic Locations of Four Weather Stations

\begin{tabular}{|l|l|l|l|l|}
\hline Station Name & Station ID & Latitude $^{\circ}$ & Longitude $^{\circ}$ & Elevation (m) \\
\hline Poway NE1 & SDPOY & 32.9606 & -117.0192 & 182 \\
\hline $\begin{array}{l}\text { Ramona } \\
\text { Airport }\end{array}$ & KRNM & 33.0375 & -116.9158 & 423 \\
\hline Escondido SPV & CI153 & 33.0810 & -116.9760 & 119 \\
\hline Julian & JULC1 & 33.0756 & -116.5917 & 1292 \\
\hline
\end{tabular}

The Weather Station at Julian is $10 \mathrm{~km}$ due East from the Witch fire origin. It displayed a wind shift from west to east early on the morning of October $21^{\text {st }} 2007$. The relative humidity ranged between $30 \%$ and $40 \%$ prior to the wind shift and was reduced to $16 \%$ by noon. By $12: 15 \mathrm{pm}$, the sustained wind at Julian was recorded at $38 \mathrm{~km} / \mathrm{hr}$ and gusting to $69 \mathrm{~km} / \mathrm{h}$. The Witch fire ignited at 12:35 pm.

The Ramona Airport weather station is $13 \mathrm{~km}$ due east from The Trails. The station recorded a dramatic drop in humidity while also recording a rapid increase in wind speed. Similar behaviors were recorded by the Poway NE1station, located $10 \mathrm{~km}$ SSE of The Trails, and are summarized in Table 2. Figure 5 displays wind speed, wind gusts, wind direction and relative humidity at Ramona airport between October $20^{\text {th }}$ and October $22^{\text {nd }}$.

Table 2: Weather Summary

\begin{tabular}{|l|l|l|l|l|l|}
\hline $\begin{array}{l}\text { Station } \\
\text { Name }\end{array}$ & Date and Time & $\begin{array}{l}\text { Wind } \\
\text { Speed } \\
\mathbf{( k m} / \mathbf{h})\end{array}$ & $\begin{array}{l}\text { Wind Gust } \\
\mathbf{( k m} / \mathbf{h})\end{array}$ & Wind Direction & $\begin{array}{l}\text { Relative } \\
\text { Humidity (\%) }\end{array}$ \\
\hline $\begin{array}{l}\text { Poway } \\
\text { NE1 }\end{array}$ & $\begin{array}{l}\text { October 21 } \\
\text { oct }\end{array}$ & 0 & 22 & North & 90 \\
\cline { 2 - 6 } & $\begin{array}{l}\text { October } 21^{\text {st }} \\
11: 45\end{array}$ & 34 & 42 & North & 14 \\
\hline $\begin{array}{l}\text { Ramona } \\
\text { Airport }\end{array}$ & $\begin{array}{l}\text { October } 21^{\text {st }} \\
00: 45\end{array}$ & 0 & 0 & East & 94 \\
\cline { 2 - 6 } & $\begin{array}{l}\text { October } 21^{\text {st }} \\
11: 53\end{array}$ & 42 & 61 & East North East & 7 \\
\hline
\end{tabular}

Escondido SPV is $2 \mathrm{~km}$ South West of the Guejito fire origin. Although the Escondido SPV data was received by MESO West it did not have the MESO West Quality Check Flag ensuring data reliability. The data displayed similar trends to the Ramona Airport data. On October 21 $1^{\text {st }}$, between 8:00 am and 10:00 am, the relative humidity dropped from $100 \%$ to $15 \%$ and the wind 
increased from $11 \mathrm{~km} / \mathrm{h}$ to $36 \mathrm{~km} / \mathrm{h}$. At the time of the Guejito fire ignition, station CI153 reported a relative humidity of $8 \%$.

Limited quantitative information is available for the weather conditions at The Trails during the morning of October $22^{\text {nd }}$. Residents and Firefighters reported “extreme” winds and a residential weather station on Polvera Avenue and facing Highland Valley registered $91 \mathrm{~km} / \mathrm{h}$ in the early morning hours. Accounting for the possible amplification of the winds due to the Highland Valley NE orientation and Northerly wind, it is estimated that wind speeds at the Trails were at least as severe as those at Ramona or Poway.

\subsection{Data Collection}

Field data collection was initiated four days after the fire by NIST personnel and CALFIRE Fire Marshals. Field measurements were initially focused on destroyed structures and extent of burn damages through the community. This focus was necessary due to the short life span of that data. Subsequent data collection was focused on the structures that survived the fire. Data included structure particulars, including building construction and roof type, proximity of combustibles to the structure, and damage to wildland and residential vegetation. The impacts of construction type on structure survivability will be addressed in the second report on this study (work in progress). Documentation included over 11000 pictures. San Diego Fire and Police departments provided critical information for the development of the event timeline. Similarly, The Trails Homeowners Association provided essential observations from residents. Additional tools used during the study included CALFIRE generated wildland fuel maps, Google Earth, Microsoft Virtual Earth and Pictometry information. ${ }^{1}$

\subsection{Wildland Fuel and Fuel Moisture}

The CALFIRE Witch Incident Fuel Map ${ }^{16}$ contains information on the Witch fire perimeter and wildland fuel type. Thirteen different fuel types were involved within the perimeter of the Witch Fire. The Highland Valley is covered primarily by Barren/Rock/Other (Fuel Model 99), with Brush (Fuel Model 5) on the western side and Agricultural Lands (Fuel Model 97) on the eastern side. The mount occupied by the Trails is surrounded by Hardwood/Longpole Pine (Fuel Model 8) to the north and west. A small amount of Brush (Fuel Model 5) can also be found on the western side of the mount and in the main ravine/chute on the northern side. The eastern side is primarily Brush, with a couple of patches of Grass (Fuel Model 1). At the base of Sycamore Creek, there is Barren/Rock/Other (Fuel Model 99) surrounding the Creek. Figures 5 through 11 show the inhomogeneities in wildland fuel on the slopes surrounding The Trails before the Witch and Guejito fires. Wildland fuels surrounding The Trails vary in type as well as density. Figures 12 and 13 show Angosto Way, which borders the northern edge of The Trials, before

\footnotetext{
${ }^{1}$ Certain commercial entities, equipment, or materials may be identified in this document in order to describe an experimental procedure or concept adequately. Such identification is not intended to imply recommendation or endorsement by the National Institute of Standards and Technology, nor is it intended to imply that the entities, materials, or equipment are necessarily the best available for the purpose.
} 
and after the fires. The extent of damage to the canopy on the northern side of Highland Valley road is clearly evident as is the lack of canopy damage up slope, near the structures. Just before the fires reached The Trails, dead fuel moisture for 1 hour fuels is estimated at less that $10 \%$.

\subsection{Fire Approach Timeline}

The following timeline data for the flame spread of the Guejito and Witch fires on the morning of October $22^{\text {nd }} 2007$ was collected from first responders ${ }^{17}$ and community residents. ${ }^{18}$ The Guejito Fire started at 1:00 am. By 1:30 am the head of the Guejito fire met with Santa Isabel Creek which bisects Guejito Creek, $3.2 \mathrm{~km}$ (2 miles) from its point of origin. This suggests an average spread rate of $6 \mathrm{~km} / \mathrm{h}(3.75 \mathrm{mph})$. Between 3:15 am and 3:20 am the head of the fire turned southwest and started down Highland Valley. By 3:50 am, the fire front had reached the intersection of Highland Valley road and Sycamore Creek, covering a distance of $4.5 \mathrm{~km}$ (2.8 miles) in a little over 30 minutes at a rate of $9.0 \mathrm{~km} / \mathrm{h}(5.6 \mathrm{mph})$. At that time the fire had reached the perimeter of The Trails. A high intensity fire (based on observations of crown damage) was concentrated around the trees on the river bed to the north of The Trails, with lower intensity burning along the valley floor.

At the time the Guejito Fire was moving southwest down Highland Valley, it was also spreading towards the intersection of Bandy Canyon/Highland Valley Road. It reached that intersection by 3:30 am and homes there began to burn.

At the same time, the Guejito fire was moving towards The Trails, the Witch Creek fire was advancing west. Because of the large magnitude of the Witch fire perimeter it has been difficult to identify its exact location over time as it approached The Trails. The following data points provide a general idea of its timeline. By 2:55 am the Witch Fire reached the San Pasqual Academy 1 kilometer ( 0.6 miles) east of the Guejito origin and $23 \mathrm{~km}$ from its own point of origin. At 6:00 am another part of the Witch Fire was making its way down Clevenger canyon 5 kilometers (3.0 miles) east of Guejito origin and $23 \mathrm{~km}$ from its own point of origin.

The Trails was assaulted by both the Guejito and the Witch fires. The main front of the Guejito Fire reached The Trails at approximately 3:45 am Monday morning October $22^{\text {nd }}$ and came from the Highland Valley. It is estimated that the Witch Fire arrived at the southeastern part of The Trails sometime around 6:00am. Figure 14 shows the topographic characteristics of The Trails and Figure 15 illustrates the approach of the Guejito and Witch fires.

\subsection{Timeline within The Trails}

The following timeline includes ember exposure, burning vegetation, and burning structure information. The chronological steps vary in duration to better capture the nature of the event. It should be noted that the available data is partial and limited in the sense that the frequency of reported observations is a function of number of the observers present, which was inconsistent and decreased with time. The timeline reconstruction focuses on the destroyed structures, while damaged structures are addressed in section 11.0, later in the document. Reported observations of structures that were ultimately destroyed are divided in four categories: (1) some visible flaming, (2) fully involved flaming, (3) almost completely burned out, and (4) destroyed with 
essentially no flames visible. In most cases, only one observation is available for a particular structure.

In the following time reconstruction for destroyed structures, burning structures were reported along with their degree of burning, when the observation was made (Figure 16). In that respect, structures that are fully involved during a time interval and binned in one time step could possibly have ignited during the previous time interval. There is therefore potentially a significant temporal uncertainty associated with the actual ignition times of the structures. Even though smoldering could had been present for hours before the flaming occurred, it is estimated that initiation of flaming combustion can be estimated to within one hour. An attempt is made to estimate structure ignition times and total number of homes burning during each time interval. This is reported later in this section. Structure burning observations are documented in Figure 17.

\section{2:00 am to 3:30 am}

Embers appear on the perimeter of the community, from the burning wildland fuels as early as 2:30 am. The first vegetation ignitions are reported at 2:30 am and 2:45 am. These ignitions were a result of spotting from the Guejito Fire which at 2:30 am was over 4.5 kilometers (2.8 miles) away. Vegetation began to burn in the interior of the community by 3:00 am. Three structures were ignited and six vegetation ignitions are reported throughout the community by 3:30. All three structures were on the north-west side of the community adjacent to or within $150 \mathrm{~m}(500 \mathrm{ft})$ from the wildlands.

\section{3:30 am to 4:30 am}

The main fireline of the Guejito Fire reached the community between 3:30 and 4:00. Embers were reported across the entire perimeter of the community as well as in the interior and there are sixteen different vegetation fires. This was the period of highest reported structure burning activity. Four additional homes were burning between 3:31 am and 3:50 am and sixteen more between 3:55 am and 4:30 am. Out of the twenty-two new homes that were reported burning in this time period, eleven were showing some flames visible, while the remaining nine were fully involved.

\section{4:30 am to $5: 30$ am}

Active ember attack was still reported across the perimeter and the interior; however the total number of ember observations was reduced to six. Vegetation burning observations were down to two. Nine additional homes were burning in this time window. Seven were showing some flames visible and two were fully involved.

\section{5:30 to 6:30 am}

An additional eight homes were reported burning in this time window, including two that were almost completely consumed. An additional two homes were completely consumed and no longer burning. It is during the end of this time interval that the Witch Fire likely arrived at The Trails from the east. Four out of the ten additional burning homes reported in this time window were on the eastern perimeter of the community.

\section{6:30 am to $10: 30$ am}

In this time window, five additional homes were burning. Additionally, there were three previously unreported homes that were identified as destroyed and no longer burning. 
10:30 am to $12: 30 \mathrm{pm}$

One new home burned in this window and eight previously unreported homes were identified as completely destroyed and no longer burning.

\section{2:30 pm to 3:15 pm}

The last home was ignited and burned in this time window. In less than twelve hours after the Guejito fire arrived at The Trails no homes were burning.

Table 3 lists the breakdown of destroyed structures as a function of time. The category, "No longer burning” refers to structures that were already destroyed at the time of the first observation. The category "Partial data" refers to structures where observations were made prior to structure ignition, i.e.: subsequently destroyed home was not burning at the time of observation. The data in the table shows that new structure burning observations peak at 22 structures / hour between 3:30 to 4:30 am. The fire spread very rapidly within the community igniting over $50 \%(41 / 74)$ of the destroyed structures within three hours after the first reported ignition. After 6:30 am, the number of new structure ignitions dramatically tapers off from eight, to one or two per hour. An expanded timeline table can be found in Figure 16.

To bound the estimate of number of homes burning in the community at any one time, the following assumptions are considered:

- It takes two hours from flaming ignition of a house to no longer burning

- Reports of homes ignited with some flames visible can be used as surrogates for structure ignition times.

- Reports of homes fully involved can be moved back one hour and used to approximate ignition in the previous time interval.

- Reports of homes almost completely destroyed can be moved back two hours and used to approximate ignition in the new time interval.

In Table 3, the rows labeled Estimated Structure Ignitions and Estimated Total Homes Burning are created using the above assumptions.

Table 3: Timeline of Completely Destroyed Structures

\begin{tabular}{|c|c|c|c|c|c|c|c|c|}
\hline Time window & $\begin{array}{l}2: 30 \\
\text { am to } \\
3: 30 \\
\text { am }\end{array}$ & $\begin{array}{l}3: 30 \\
\text { am to } \\
4: 30 \\
\text { am }\end{array}$ & $\begin{array}{l}4: 30 \\
\text { am to } \\
5: 30 \\
\text { am }\end{array}$ & $\begin{array}{l}5: 30 \\
\text { am to } \\
6: 30 \\
\text { am }\end{array}$ & $\begin{array}{l}6: 30 \\
\text { am to } \\
10: 30 \\
\text { am }\end{array}$ & $\begin{array}{l}10: 30 \\
\text { am to } \\
12: 30 \\
\text { pm }\end{array}$ & $\begin{array}{l}12: 30 \\
\text { pm to } \\
3: 15 \\
\text { pm }\end{array}$ & Total \\
\hline $\begin{array}{l}\text { Ignited- some flames } \\
\text { visible }\end{array}$ & 3 & 12 & 7 & 2 & 1 & 1 & 0 & 26 \\
\hline Fully involved & 0 & 10 & 2 & 4 & 2 & 0 & 1 & 19 \\
\hline $\begin{array}{l}\text { Almost completely } \\
\text { destroyed }\end{array}$ & 0 & 0 & 0 & 2 & 1 & 0 & 0 & 3 \\
\hline New burning & 3 & 22 & 9 & 8 & 4 & 1 & 1 & 48 \\
\hline $\begin{array}{l}\text { New No longer } \\
\text { burning* }\end{array}$ & 0 & 0 & 0 & 0 & 1 & 4 & & 5 \\
\hline Total & 3 & 22 & 9 & 8 & 5 & 5 & 1 & 53 \\
\hline Cumulative Total & 3 & 25 & 34 & 42 & 47 & 52 & 53 & 53 \\
\hline Partial data** & 2 & 7 & 3 & 3 & & & & 15 \\
\hline
\end{tabular}




\begin{tabular}{|l|l|l|l|l|l|l|l|l|}
\hline Unknown & & & & & & & & 6 \\
\hline Grand Total & & & & & & & & 74 \\
\hline $\begin{array}{l}\text { Estimated Structure } \\
\text { Flaming Ignitions }\end{array}$ & 13 & 16 & 12 & 4 & 1 & 1 & 1 & n/a \\
\hline $\begin{array}{l}\text { Estimated Total } \\
\text { Homes Burning }\end{array}$ & 13 & 29 & 26 & 16 & 5 & 2 & 2 & n/a \\
\hline
\end{tabular}

n/a - not applicable

* Only data available

** Partial data: destroyed structures were not burning at the time of observation

\subsection{Fire Spread within The Trails}

Different tools were used to document fire spread within The Trails. The extent of burned vegetation was documented along with the locations the fire jumped a road. Several different indicators were used to determine the direction that the fire spread. The use of the different indicators will be explained in this section. In the wildlands, needle freeze as defined below, directional degree of damage to wildland vegetation and the presence of partly damaged golf balls were all used to determine directionality of fire spread. In this document, the perimeter of The Trails is defined by all lots that have direct contact with the wildlands.

Within The Trails, vegetation was burned on both sides of a road, implying spotting across the road, 21 times. Out of those, 18 were on the perimeter of the community and the remaining three on interior roads. Out of the 18 road jumps along the perimeter region, 15 were located on lots with destroyed structures on the perimeter side of the road and 2 out of the remaining 3 were located at lots adjacent do destroyed structures. Additionally, 10 out the 18 jumps had destroyed homes on both sides. It is not known if the fire jumps occurred before or after the structures on the perimeter were burning. That is, it is not clear whether embers generated by burning vegetation or structures caused the spotting.

The limited data available do show that in the perimeter region, there are two cases were structures in the interior ignited before structures on the perimeter. It is therefore possible that the wildland front ignited interior structures $0.2 \mathrm{~km}$ ( $1 / 8$ mile) from the perimeter. This hypothesis, however, cannot be confirmed because of the limited spatial/temporal resolution of the currently available data. Flame spread information was obtained from direct observation of burned vegetation.

Needle freeze information, the process of dehydrated foliage aligning or "freezing" parallel to the wind direction, was also used to obtain wind direction. ${ }^{19}$ Figure 18 illustrates flame spread and needle freeze around and within The Trails.

A survey of the perimeter of The Trails and valley floor identified a number of golf balls that were partially embedded in the ground. These were used to obtain general quantitative information of the direction of the oncoming fire front, or highest heat flux since the surface of the golf ball facing the direction of the oncoming fire front melted (Figure 19). GPS coordinates and a compass heading were used to document this information. The yellow arrows in Figure 17 depict the information collected by the geo-located golf balls. The general flame spread direction information obtained from the golf balls matches the other flame spread information collected from first responders. 
Figures 17 and 20 illustrate the fire line progression within The Trails. The fire lines, represented with solid lines in Figure 20, are assembled by joining together the observations at different times throughout the community. A fire line data point is associated with either vegetation or a structure burning. The two earliest reports of fire in the community occur at 2:30 in the morning, over an hour before the main fire front arrived from the wildlands at 3:50 am. Between 2:45 am and 3:10 am, there were three reports of embers on the northern part of the community. Reports of embers on the Sycamore Creek side (eastern side) were provided at 3:50 am, the same time the main fire front reached The Trails. The fire line then progressed in the community by moving further on the eastern and western sides where wildland fuel is present and almost reaches its final configuration by 5:30 am. Based on first responder accounts, the wind veered from the northeast to the east shortly before 6:00 am. This wind shift arrived at the Trails, shortly before the Witch fire. It is likely that the shift in wind direction, slowed and eventually stopped the fire spread within the Trails, however, given the data available, this cannot be confirmed.

Figure 20 uses four different bins to illustrate the extent of structures burning within the community. Between 2:30 am and 3:55 am, the Guejito fire ignited structures on the northwestern part of The Trails, and primarily on the perimeter. Over the next two hours, between 4:00 am and 5:55 am, the structures burning in the interior reached $500 \mathrm{~m}$ (1/3 mile) in from the perimeter, the furthest into the community. Between 6:00 am and 9:55 am five new homes are burning on the eastern side of The Trails, with three additional homes burning throughout the community. Between 10:00 am and 1:30 pm, seven more homes burned.

\subsection{Structure Exposure to Fire and Embers}

Embers from the wildlands were observed in the community as early as 2:30 am, well before the main fire front which arrived at 3:50 am. The embers that arrived before the main front contributed to three structure ignitions or less than $5 \%$ of the total destroyed structures. This is based on multiple first hand observations from first responders (police and fire) and homeowners. Additionally, there were six documented separate vegetation ignitions from embers. Most of the damage to structures and vegetation was done by the main fire front which arrived approximately one hour later.

The relationship between wildland fuel and the number of destroyed structures in two areas of The Trails requires consideration. From reference 15, the CALFIRE Witch Incident Fuel Map, the wildland fuel down slope of Angosto Way (western end of the northern perimeter) consisted of hardwood/long pole pine trees. Direct observations and discussions with SDFD and home owners confirmed the presence of significant surface litter. Despite the fact the wildland fire did not transition to crowning in that location, seven out of nine homes on that road were destroyed. Additionally, of the two remaining structures, one was actively defended.

The wildland fuel adjacent to Polvera Avenue (north perimeter) varied as a function of location. On the western side, Angosto Way was at lower elevation than Polvera Avenue and had significant coverage of hardwood with surface litter. From Olmeda Place (center of northern perimeter) to the eastern end of the northern perimeter, the fuels consisted of intermixed hardwoods and brush. At the eastern end of Polvera Avenue there is a rock outcrop, see Figure 
21. This outcrop reduced the local wildland fuel loading and provided a fire break for the structures to the north (upslope) of it.

On the eastern perimeter of the community, the fuel down slope of Aceituno Street was primarily brush with one patch of hardwood threes covering approximately one hectare $(2.47$ acres) and one patch of grass of approximately the same size. The damage to the wildland fuels was extensive in this area. The structural damage along Aceituno Street was focused on the wildland side of the street, with seven out of nine homes destroyed compared to two out of nine on the western (i.e., interior) part. Out of the two surviving structures on the perimeter, both were damaged and one had been defended.

The exposure to embers within the community varied with location and time. Ember exposure reached further into the community with time as the main front arrived. The presence of embers continued to increase as more structures were ignited on the perimeter and within the community. Unlike on the perimeter of the community where the presence of embers preceded the main fire front by approximately one hour, in the interior, the data available does not allow us to differentiate spatially between ignitions by embers or by the fire front.

\subsection{Defensive Actions}

A number of defensive and fire suppression actions were taken in The Trails before, during and after the arrival of the Guejito and Witch fires. Documenting defensive actions is essential to correctly interpreting fire behavior and structure survivability data. Defensive actions are defined here as actions taken by SDFD (San Diego Fire Department), SDPD (San Diego Police Department) and homeowners to slow down, redirect, control and extinguish any fires during the morning of October $22^{\text {nd }}$, 2007. No attempt will be made to examine SDFD and SDPD doctrines, policies or decision making. The purpose of this section is to examine the actions taken in the context of structure survivability. In that context, in order to develop a more complete understanding of structure ignitions mechanisms and conditions as well as correctly interpreting structure survivability data, defensive actions must be documented.

A case is presented here to illustrate this. A homeowner was convinced that his house survived because he turned on the lawn sprinkler system the evening before the fire arrived but was unaware that a fire engine had spent two hours defending his house. It is not possible to accurately estimate the total impact of all defensive actions; however, the effects of defensive actions on damaged structures are clearly seen as 15 out the 16 damaged structures were defended (see Section 11.0).

The focus of the analysis is on all actions taken shortly before the approach of the Guejito fire and for approximately the 12 hours after its arrival, or until 3:00 pm Monday afternoon. Figure 22 illustrates the impacts of the identified defensive actions taken at The Trails during that period. Although fires reignited and new spot fires were started after that period, no homes were ignited after 1:30 pm and all major fire suppression activity was significantly reduced.

Data collection and technical discussions were conducted with the SDFD, SDPD and The Trails Home Owners Association. A total of 86 actions were identified at The Trails, between 2:00 am and 3:00 pm Monday October $22^{\text {nd }}$, however there is no way of knowing how many actions 
were not identified. The actions ranged in complexity and scope from SDFD fire engine crew defending a house with multiple fire hoses to a homeowner putting out a gutter fire with a garden hose. Out of the 86 identified actions, 47 actions taken by SDFD and 39 actions were identified as taken by SDPD or residents of the trails.

\section{Perimeter versus Interior}

Out of the 86 identified actions, 32 were on the perimeter and the remaining 53 in the interior of The Trails. In relative terms, defensive actions were identified on $39 \%$ of perimeter structures and $32 \%$ of interior structures. Half of the actions taken by SDFD, were on the perimeter and the remaining half were in the interior of The Trails.

\section{Structures on Fire}

There were 11 fire containment actions and 25 defensive actions aimed at saving structures on fire. San Diego FD, Police and homeowners all contributed to suppressing homes on fire. Out of the 25 defensive actions taken on structures on fire, 15 were successful yielding a success rate of $60 \%$. Ten of the defended homes on fires were lost. Additionally, due to the extreme rate of structure ignitions and the limited number of resources available $53 / 74$ or $70 \%$ of the destroyed homes were not defended. Lastly, 50 actions were taken on undamaged structures with unknown influence on structure survivability. Figure 23 illustrates the relationships between the defensive actions taken and the numbers of structures damaged or destroyed.

\subsection{Timeline of actions}

Technical discussions with the SDFD identified that a strike team of six engines was at The Trails at approximately 2:45 am. At 3:00 am, after a short safety brief, the engines took their positions around The Trails. Many residents were still in The Trails and out of the six engines; three were involved in resident evacuations. The remaining three engines worked on protecting residences for the next three hours.

At approximately 6:00 am, the SDFD engines left The Trails to pursue the Guejito fire. SDFD returned at The Trails at approximately 10:00 am, with at least 7 engines, and remained there, with different crews, until the event was over well into Tuesday.

SDPD started arriving at the scene at approximately 3:30 am. Over 80 police officers were involved in the evacuation of residents from the Trails community. The majority of the evacuation occurred between 4:00 am and 6:00am. At 4:30 am a small fraction of the police personnel left The Trails. The remaining Police personnel patrolled the neighborhood and contributed to fire suppression and control, however the defensive actions taken by SDPD after 4:30 am were not documented due to NIST resource limitations and could not be differentiated from resident defensive actions.

Table 4 contains information on the timeline of defensive actions. Table 5 contains timeline information on the destroyed homes that were defended. Information on the damaged homes can be found in section 11.0 of this paper. There were 48 separate San Diego Fire Department actions identified, including 30 that were taken before 3:15 pm. Additionally, there were 30 separate actions taken by The Trails residents and San Diego PD, 14 of which were identified as taken before 3:15 pm. 
Table 4: Timeline of Defensive Actions

\begin{tabular}{|l|c|c|c|c|}
\hline $\begin{array}{l}\text { Time } \\
\text { window }\end{array}$ & $\mathbf{2 : 3 0}$ am to 6:30 am & $\mathbf{6 : 3 0}$ am to 10:30 am & $\mathbf{1 0 : 3 0}$ am to 3:15 pm & $\begin{array}{l}\text { Total } \\
\text { Known }\end{array}$ \\
\hline SDFD & 12 & $\begin{array}{c}\text { No fire suppression/ } \\
\text { control actions }\end{array}$ & 18 & 30 \\
\hline SDPD & $\begin{array}{c}\text { No fire suppression/ } \\
\text { control actions }\end{array}$ & $\begin{array}{c}\text { All SDPD fire suppression/ control actions started } \\
\text { after approximately 6:30 am }\end{array}$ & - \\
\hline Resident & 7 & 5 & 2 & 14 \\
\hline
\end{tabular}

Out of the 12 homes that were defended when burning, attempts were made to save 8 . Out of these the eight, four were defended when the Guejito fire hit the community, one shortly after 10:00 am and the remaining three between noon and 1:30 pm.

Table 5: Homes that were defended while burning

\begin{tabular}{|c|c|c|c|c|c|c|c|c|}
\hline $\begin{array}{l}\text { Time } \\
\text { window }\end{array}$ & $\begin{array}{l}2: 30 \\
\text { am to } \\
3: 30 \\
\text { am }\end{array}$ & $\begin{array}{l}3: 30 \\
\text { am to } \\
4: 30 \\
\text { am }\end{array}$ & $\begin{array}{l}4: 30 \\
\text { am to } \\
5: 30 \\
\text { am }\end{array}$ & $\begin{array}{l}5: 30 \\
\text { am to } \\
6: 30 \\
\text { am }\end{array}$ & $\begin{array}{l}6: 30 \\
\text { am to } \\
10: 30 \\
\text { am }\end{array}$ & $\begin{array}{l}10: 30 \\
\text { am to } \\
12: 30 \\
\text { pm }\end{array}$ & $\begin{array}{l}12: 30 \\
\text { pm to } \\
3: 15 \\
\text { pm }\end{array}$ & Total \\
\hline $\begin{array}{l}\text { Ignited- } \\
\text { some } \\
\text { flames } \\
\text { visible } \\
\end{array}$ & 2 out 3 & 2 out 11 & 1 of 5 & 0 of 2 & 1 of 1 & 2 of 2 & 0 & $8 / 24$ \\
\hline $\begin{array}{l}\text { Fully } \\
\text { involved }\end{array}$ & 0 & 1 out 9 & 0 of 2 & 0 of 4 & 0 of 2 & 0 & 1 of 1 & $2 / 18$ \\
\hline $\begin{array}{l}\text { Almost } \\
\text { completely } \\
\text { destroyed }\end{array}$ & 0 & 0 & 0 & 0 of 2 & 2 of 2 & 0 & 0 & $2 / 4$ \\
\hline $\begin{array}{l}\text { Defended } \\
\text { while } \\
\text { burning }\end{array}$ & 2 of 3 & 3 of 20 & 1 of 7 & 0 of 8 & 3 of 5 & 2 of 2 & 1 of 1 & $12 / 46$ \\
\hline
\end{tabular}

Between 3:00 am and 3:00 pm, the San Diego Fire Department saved eight structures, where ignitions had taken place (see next section) and attempted to save an additional 10 that were lost. In addition, actions were taken on 11 structures to contain or overhaul the fire (reducing the potential for secondary fires). Additional actions were also taken that affected fire behavior and reduced fire severity; however, they were not directly linked to the survival of particular structures. Such actions included the displacement of flammable materials from the vicinity of structures and the suppression of spot fires.

\subsection{Partly Damaged Structures}

Out of the 245 homes within the fire line, 16 homes (7 \%) were damaged compared to 74 homes (30 \%) destroyed. Numerous additional properties suffered sometimes extensive smoke damage that is not addressed here. Burned ornamental vegetation, sometimes extensive, is also not covered here. The 16 damaged structures addressed here had varying degrees of damage ranging from burned detached garages to small amounts of burn damage on the main house. 
Identified defensive actions were taken on 15 out of the 16 homes. Table 6 lists type of damages and the time, if known, and type of detailed defensive action taken. Out of the fifteen defended structures, eight were defended by SDFD and five by residents or SDPD. For one damaged structure no defensive actions has been reported to date. Four out of the fourteen defensive actions occurred before 6:00 am, while the remaining seven occurred after $8 \mathrm{am}$, and the times for two defensive actions have not been identified. Figure 24 contains the locations of the damaged homes; numbers on Figure 24 correspond to House Number in Table 6.

Table 6: Damaged Structures and Defensive Actions

\begin{tabular}{|c|c|c|c|}
\hline $\begin{array}{l}\text { House } \\
\text { Number }\end{array}$ & $\begin{array}{l}\text { Damaged area/ } \\
\text { ignition location }\end{array}$ & Defensive Action (party responsible) & $\begin{array}{l}\text { Time Action } \\
\text { was Taken }\end{array}$ \\
\hline 1 & $\begin{array}{l}\text { decking and railroad } \\
\text { ties }\end{array}$ & $\begin{array}{l}\text { Garden hose used to extinguish fires } \\
\text { (resident or SDPD) }\end{array}$ & before 6:00 am \\
\hline 2 & $\begin{array}{l}\text { detached garage and } \\
\text { corner of main house/ } \\
\text { unknown }\end{array}$ & Fire contained in garage (SDFD) & $\begin{array}{l}\text { 10:00 am to } \\
\text { noon }\end{array}$ \\
\hline 3 & $\begin{array}{l}\text { detached garage/ } \\
\text { unknown }\end{array}$ & Fire contained in garage (SDFD) & $\begin{array}{l}\text { 10:00 am to } \\
\text { noon }\end{array}$ \\
\hline 4 & $\begin{array}{l}\text { Structure addition } \\
\text { under construction }\end{array}$ & $\begin{array}{l}\text { Water from suppression evident } \\
\text { (SDFD) }\end{array}$ & unknown \\
\hline 5 & $\begin{array}{l}\text { main structure/ outside } \\
\text { column (stucco over } \\
\text { wood) }\end{array}$ & $\begin{array}{l}\text { Fire contained to outside column } \\
\text { (SDFD) }\end{array}$ & after 3:00 pm \\
\hline 6 & $\begin{array}{l}\text { detached garage/ } \\
\text { unknown }\end{array}$ & Fire contained in garage (SDFD) & $\begin{array}{l}\text { 10:00 am to } \\
\text { noon }\end{array}$ \\
\hline 7 & $\begin{array}{l}\text { detached structure/ } \\
\text { unknown }\end{array}$ & $\begin{array}{l}\text { Fire contained in detached structure } \\
\text { (resident or SDPD) }\end{array}$ & $7: 00 \mathrm{am}$ \\
\hline 8 & $\begin{array}{l}\text { main structure/ exposed } \\
\text { wood beam }\end{array}$ & $\begin{array}{l}\text { Garden hose used to extinguish fires } \\
\text { (resident) }\end{array}$ & 8:00 am \\
\hline 9 & decking & Garden hose and bucket (resident) & 9:00 am \\
\hline 10 & main structure/ gutter & $\begin{array}{l}\text { Garden hose used to extinguish fires } \\
\text { (resident) }\end{array}$ & $\begin{array}{l}\text { 3:00 am to } 5: 00 \\
\text { am }\end{array}$ \\
\hline 11 & decking & Garden hoses used (unknown) & $\begin{array}{l}\text { 3:00 am to } 6: 00 \\
\text { am }\end{array}$ \\
\hline 12 & $\begin{array}{l}\text { detached wood shed, } \\
\text { wood fencing }\end{array}$ & Fire contained (SDFD) & $\begin{array}{l}\text { 3:00 am to } 6: 00 \\
\text { am }\end{array}$ \\
\hline 13 & decking & $\begin{array}{l}\text { Fire contained to location of origin } \\
\text { (SDFD) }\end{array}$ & $\begin{array}{l}\text { 3:00 am to } 6: 00 \\
\text { am }\end{array}$ \\
\hline 14 & roof top solar panels & Spot fires extinguished (SDFD) & after 10:00 am \\
\hline 15 & deck and main structure & $\begin{array}{l}\text { Fire contained to location of origin } \\
\text { (unknown) }\end{array}$ & unknown \\
\hline 16 & $\begin{array}{l}\text { main structure/ wood } \\
\text { crate }\end{array}$ & None known & - \\
\hline
\end{tabular}

It is not possible to know how the fire would have progressed if no defensive actions had taken place. There was only one damaged and unprotected structure within the Trails. The other 15 
damaged structures were defended. Since 15 of the sixteen damaged structures were defended, it is very likely that most if not all ignited structures would have been destroyed had there been no defensive actions. In that case, the destroyed to total ratio would have increased from 30 to a minimum of $37 \%$ for The Trails.

\subsection{Interior versus Perimeter Structural losses}

In this study, the perimeter of the community is defined by the lots that have a portion of their perimeter adjacent to wildlands. Figure 25 shows the interior and perimeter boundary for The Trails. Out of the 74 destroyed structures, 38 were on the perimeter and the remaining 36 in the interior of the community. Forty percent of homes on the perimeter were destroyed (36/82), compared to twenty percent in the interior (36/163). As described in section 9.0, there was significant wildland fuel variability around The Trails. This fuel type and loading variability resulted in locally different fire and ember exposures. In the interior of the community, structure losses were a result of exposure to embers generated from burning wildland and residential vegetation and structural fuels.

\subsection{Structure Ignition Data}

In the two weeks after the Guejito and Witch fires reached the Trails, the damage to vegetation and the particulars of the destroyed homes were documented. The initial focus on the destroyed structures was aimed at collecting the necessary information prior to the initiation of cleanup and reconstruction. Three categories were defined to characterize potential structure ignitions.

Category A - Uninterrupted Vegetative Fire or Ember Ignition

Category A was defined as potential structure ignitions due to uninterrupted fire spread though vegetation to the structure. This category is by definition limited to the perimeter of the community as roads provide a vegetative fuel break. Figure 26 shows an example of a Category A structure. The 19 structures in this category had burned vegetation right up to the structure. In all 19 cases, residential vegetation carried the fire to the structure. Note, that there is no way to determine, short of an eyewitness account, if the vegetation was responsible for the ignition of the structure or if embers had resulted in structure ignition independently.

\section{Category B - Vegetative Fire or Ember Ignition}

The Category B was defined as structures where there was sufficient burned vegetation around the structure to be a potential source of structure ignition; however this vegetation near the structure could not have ignited due to continuous fire spread through vegetative fuels. In this case, it was assumed that the vegetation near the structure was ignited via embers. Figure 27 shows an example of a Category B structure. The vegetative fuel discontinuity meant that the ignitions of structures in category B, involved embers. Embers were involved in either igniting residential vegetation or directly igniting the structure. Table 7 shows that the 35 structures in category B were not limited to the interior of the community, with almost one out of every three being on the perimeter of The Trails.

\section{Category C- Ember Ignition}

Category C, with 20 out of the 74 destroyed structures, was defined as structure ignitions that were a direct result of embers. Figure 28 shows an example of a Category $\mathrm{C}$ structure. This was 
determined from the very limited damage to vegetation surrounding the structure. There were structures in both the interior and the perimeter of the community that fell in this Category.

Direct flame impingement from structure to structure ignitions was not identified as a significant contributor to fire spread within The Trails. Out of the 74 homes that were destroyed only two sets were closer that $13.5 \mathrm{~m}$ (45 ft). This observation does not apply to embers generated from burning structures, as there are several reports of structures coming apart in the high Santa Anna winds and generating large quantities of embers ranging up to golf ball size and larger.

Embers could have potentially ignited all structures. However, conservatively, ember ignitions are the sum of structures in Categories B and C which is 55 out of the 74 destroyed structures. Thus, in this particular scenario, over two out of every three structure ignitions involved embers. Embers were involved either by igniting vegetation that could have ignited the structure (Category B), or by direct ignition of the structure (Category C).

The distribution of Categories A, B, and C in the perimeter and interior of The Trails are listed in Tables 7 through 9. Out of the 245 structures that were within the fire line 163 were in the interior of the community and 82 were on the perimeter.

While Category A is found only on the perimeter of the community by definition, Categories B and $\mathrm{C}$ are found both on the perimeter and in the interior of The Trails. Category B, with 35 out of the 74 destroyed structures, has the largest percentage of structures of all three Categories.

The ratio of interior structures in ignition Category B (IB) to the total number of interior structures (IT) is 0.15 . This is identical to the ratio of perimeter structures in ignition Category $\mathrm{B}$ (PB) over the total number of perimeter structures (PT) indicating that spotting was involved equally in the ignition of perimeter and interior structures.

The equivalent ratios for ignition Category $C$ have respective values of 0.075 and 0.10 . While not identical, the numbers are very similar indicating that embers were a direct source of structure ignitions on the perimeter as well as in the interior of this community.

Table 7: Ignition Categories A, B, and C

\begin{tabular}{|l|l|l|l|}
\hline $\begin{array}{l}\text { Ignition Category A - } \\
\text { Uninterrupted fire } \\
\text { spread through } \\
\text { vegetation (19/74) }\end{array}$ & $\begin{array}{l}\text { Ignition Category B - } \\
\text { Fire spotting over } \\
\text { residential vegetation }\end{array}$ & $\begin{array}{l}\text { Ignition Category C - } \\
\text { Embers* }\end{array}$ & Total \\
\hline (35/74) & & \\
\hline Perimeter: $19 / 19$ & Perimeter: 11/35 & Perimeter: 8/20 & \\
\hline Interior: - & Interior: 24/35 & Interior:12/20 & Perimeter: 38 \\
\hline
\end{tabular}


Table 8: Homes Destroyed - Interior

\begin{tabular}{|l|l|l|}
\hline $\begin{array}{l}\text { Ignition Category A - } \\
\text { Uninterrupted fire spread } \\
\text { through vegetation } \\
\mathbf{A}=\mathbf{1 9}\end{array}$ & $\begin{array}{l}\text { Ignition Category B - } \\
\text { Fire spotting over residential } \\
\text { vegetation } \\
\mathbf{B}=\mathbf{3 5}\end{array}$ & $\begin{array}{l}\text { Ignition Category C - } \\
\text { Embers* }\end{array}$ \\
\hline $\mathrm{IA}=0$ & $\mathrm{IB}=24$ & IC $=12$ \\
\hline $\mathrm{IA} / \mathrm{A}: \mathrm{N} / \mathrm{A}$ & $\mathrm{IB} / \mathrm{B}: 24 / 35(0.70)$ & IC/C: $12 / 20(0.60)$ \\
\hline $\mathrm{IA} / \mathrm{IT}: \mathrm{N} / \mathrm{A}$ & $\mathrm{IB} / \mathrm{IT}: 24 / 163(0.15)$ & IC/IT $: 12 / 163(0.075)$ \\
\hline
\end{tabular}

Table 9: Homes Destroyed - Perimeter

\begin{tabular}{|l|l|l|}
\hline $\begin{array}{l}\text { Ignition Category A - } \\
\text { Uninterrupted fire spread } \\
\text { through vegetation } \\
\mathbf{A}=\mathbf{1 9}\end{array}$ & $\begin{array}{l}\text { Ignition Category B - } \\
\text { Fire spotting over residential } \\
\text { vegetation } \\
\mathbf{B}=\mathbf{3 5}\end{array}$ & $\begin{array}{l}\text { Ignition Category C - } \\
\text { Embers* }\end{array}$ \\
\hline $\mathrm{PA}=19$ & $\mathrm{~PB}=11$ & $\mathbf{C}=\mathbf{2 0}$ \\
\hline $\mathrm{PT} / \mathrm{A}: 19 / 19(1.0)$ & $\mathrm{PB} / \mathrm{B}: 11 / 35(0.30)$ & $\mathrm{PC} / \mathrm{C}: 8 / 20(0.40)$ \\
\hline $\mathrm{PA} / \mathrm{PT}: 19 / 82(0.25)$ & $\mathrm{PB} / \mathrm{PT}: 11 / 82(0.15)$ & $\mathrm{PC} / \mathrm{PT}: 8 / 82(0.10)$ \\
\hline
\end{tabular}

The time distribution of Potential Structure Ignition Categories A, B, and C are described in Table 10. Seven out of the twelve time-distributed As, or $60 \%$, were first observed burning between 3:31 and 4:30 am. Similarly twelve out of twenty-two Bs, or $55 \%$, and four out of twelve Cs, or $30 \%$, were burning during that same time window. From 4:30 am to 3:15 pm, the limited data in the table show that the Bs and Cs have almost the same time history. Figure 29 shows how the As, Bs and Cs are spatially and temporally distributed.

Table 10: Time Distribution of Potential Structure Ignition Categories A, B, and C

\begin{tabular}{|c|c|c|c|c|c|c|c|c|c|}
\hline $\begin{array}{l}\text { Time } \\
\text { window }\end{array}$ & $\begin{array}{l}2: 30 \\
\text { am to } \\
3: 30 \\
\text { am }\end{array}$ & $\begin{array}{l}3: 30 \\
\text { am to } \\
4: 30 \\
\text { am }\end{array}$ & $\begin{array}{l}4: 30 \\
\text { am to } \\
5: 30 \\
\text { am }\end{array}$ & $\begin{array}{l}5: 30 \\
\text { am to } \\
6: 30 \\
\text { am }\end{array}$ & $\begin{array}{l}6: 30 \\
\text { am to } \\
10: 30 \\
\text { am }\end{array}$ & $\begin{array}{l}10: 30 \\
\text { am to } \\
12: 30 \\
\text { pm }\end{array}$ & $\begin{array}{l}12: 30 \\
\text { pm to } \\
3: 15 \\
\text { pm }\end{array}$ & $\begin{array}{l}\text { Partial or } \\
\text { unknown } \\
\text { time data }\end{array}$ & Total \\
\hline A & 1 & 7 & 1 & 2 & 1 & 0 & 0 & 7 & 19 \\
\hline B & 2 & 12 & 3 & 2 & 2 & 1 & 0 & 13 & 35 \\
\hline $\mathrm{C}$ & 0 & 4 & 3 & 2 & 2 & 0 & 1 & 8 & 20 \\
\hline Total & 3 & 23 & 7 & 6 & 5 & 1 & 1 & 38 & \\
\hline $\begin{array}{l}\text { Cumulative } \\
\text { Total }\end{array}$ & 3 & 26 & 33 & 39 & 44 & 45 & 46 & 74 & 74 \\
\hline
\end{tabular}

\subsection{Commonly held beliefs in light of these findings}

This study focused on only $5 \%$ of the structure losses from the Guejito and Witch fires. The area of study is not one where individual homes were spaced on 16 hectare (40 acre) lots where 
homeowners have tens of meters of defensible space around their homes. The Trails is a suburban development on the edges of Rancho Bernardo with lots ranging from 0.5 hectare to 2 hectares (1.25 acres to 5 acres). Several observations were made during this study that contradict some commonly held beliefs. It had been believed that only homes on the perimeter ignite from the wildland assault. This was not the case in The Trails, where homes on the perimeter and in the interior of the community started burning before the wildland front arrived at the community.

Another common belief is that homes only take 40 minutes to burn. In reality, burn time is a function of construction material, home size, home configuration, and weather (wind). Observations from first responders and homeowners confirm that several homes burned for over two hours. Lastly, it is frequently believed that in extreme events like the Witch fire, no defensive actions are taken to protect structures. In the case of The Trails, research had identified that one out of every three homes was defended by the home owners, fire or police department personnel. These defensive actions significantly affected fire behavior and structure survivability and should be an essential component of WUI post fire case studies.

\subsection{Summary of findings and discussion}

The Witch fire was spreading towards the Rancho Bernardo area of San Diego, CA when the Guejito fire ignited. The proximity of the Guejito fire origin to the Rancho Bernardo area dramatically reduced the available time for resident evacuation and resource deployment. The net result was that in The Trails, resident evacuation was conducted as the fire reached the community. Additionally, half of the fire fighting resources available were involved in resident evacuation. The impact of the Guejito fire from embers (spotting ignitions) before the main fire front reached the community was very limited with only three home ignitions and six reported vegetative fires. The arrival of the front at approximately 3:45 am resulted in a very rapid increase in structure ignitions, exceeding 20 per hour at its peak. As the structure ignitions continued, however the rate decreased to nine per hour by 5:30 am then to eight per hour by 6:30 am. After the Witch fire reached the community, shortly after 6:00 am, the ignitions of structures dropped to one or two per hour.

The rapid ignition of structures after the main fire attack demonstrates that, with the limited available resources, effective fire prevention is essential to reducing losses. Tested and implementable guidance for homeowners, communities and land use officials are essential to reducing losses in the future.

The contributions of the SDFD, SDPD and homeowners significantly reduced the losses from these fires. Thirty percent of structures within the fireline were defended. Actions by the SDFD saved a number of homes as did actions from homeowners. Even though structures were saved by residents, in the case of The Trails, smoke inhalation, egress considerations, and limited visibility all contributed to generating a very high risk environment. Many additional actions were taken that limited fire spread, however, their effects are not traceable.

The development of a timeline for fire spread through the wildland fuels and then through The Trails has been able to provide insights on fire behavior at the WUI. Figure 30 summarizes much of the spatial and temporal information. The findings to date are divided into two categories; general fire behavior, and defensive actions and structural losses. 


\subsection{General Fire Behavior}

- $\quad$ The Guejito fire approached The Trails at a fire spread rate of $9 \mathrm{~km} / \mathrm{h}$.

- $\quad$ Fire spread rate within the community dropped to $0.35 \mathrm{~km} / \mathrm{h}$.

- Embers from the approaching wildland fire front started arriving at the community an hour before the main fire front, traveling a distance of $9.0 \mathrm{~km}$.

- The ignitions generated by embers prior to the arrival of the main fire front were limited to three homes and several patches of ornamental vegetation. These ignitions occurred $9.0 \mathrm{~km}$ ahead of the main front.

- $\quad$ Fire spread up to $500 \mathrm{~m}$ into the interior of the community.

\subsection{Structural Losses and Defensive Actions}

- $\quad$ The arrival of the wildland fire front, not the preceding embers, caused the majority of the damage and overwhelmed the first responder resources.

- $\quad 70 \%$ of the destroyed homes were not defended.

- $60 \%$ of defended structures on fire were saved.

- Over 50 \% of the structures were ignited within 3 hours after the main front of the Guejito fire hit the community.

- At its peak; right when the wildland fire front reached the community, structure ignitions reached 21 per hour.

- It is estimated that 29 of the destroyed structures (40\%) were burning at the same time.

- Two out of every three destroyed homes were ignited directly or indirectly by embers.

- Direct embers ignitions occurred from the arrival of the wildland fire front and for the next nine hours.

- Direct ember ignitions accounted for one out of every three destroyed homes.

- Embers were responsible for the ignitions of structures on the perimeter and in the interior of the community.

- $\quad 40 \%$ of structures on the perimeter were destroyed compared to $20 \%$ in the interior of the community.

- Defensive actions were taken on one out of every three homes in The Trails.

- $\quad$ Fifteen out the sixteen damaged homes were successfully defended. No defensive actions have been identified on the sixteenth damage home.

- Impact of defensive actions was significant, and probably reduced losses from over $37 \%$ down to $30 \%$.

\subsection{Unanswered Questions}

Despite the extensive data collection and analysis, there are several questions that remain unanswered. The information available has not been sufficient to determine how many home ignitions were a direct result of the wildland fire and how many resulted from structure to structure fire spread via structure generated embers. Additionally, the full impact of all the defensive actions was not quantified. Even though it is likely that most of the 15 damaged structures would have burned without intervention, over 60 documented actions were taken with potentially significant yet unquantifiable ramifications to fire spread and structure ignitions. To provide implementable risk reduction technologies, the fire and ember exposure needs to be 
characterized. Post fire studies, laboratory and field experiments and fire modeling are needed to capture the true flame and embers exposures and structure vulnerabilites.

The reach of the wildland fire into the community was not determined. The limited data available shows that in the vicinity of fire jumps from the perimeter to the interior of the community, there are two cases were structures in the interior ignited before structures on the perimeter. It is therefore possible that the wildland fire front ignited structures $0.2 \mathrm{~km}$ in from the perimeter. This hypothesis, however, cannot be confirmed because of the limited spatial/temporal resolution of the currently available data. Additional information to answer this question should be collected in the future in the form of highly temporally resolved structure burning. This may be accomplished by ground observations or remote sensing platforms such as unmanned aerial systems.

\subsection{Future Work}

There is a need for more case studies of entire fires. This study only focused on $5 \%$ of the losses from the Guejito and Witch fires. Future studies should explore how different types of neighborhoods behave under different WUI fire conditions. The influence of type of construction, age of homes (affected by different building codes) and housing density should all be explored. Structure ignition from the wildland fire versus burning structures should also be characterized for different housing densities and constructions.

At NIST, work on the Witch and Guejito fires will continue. A second report is being developed on the structural response of homes in The Trails. The primary objective of the second report is to examine how structure construction and landscaping attributes affected structure survivability. Exposure to embers and radiation as well as the defensive actions will again be factored in. Specifically, as mentioned in the introduction, the second paper will "apply" different WUI hazard reduction guidelines to the community and determine how well the guidelines match the observed structure responses to the fire. The third paper will compare the outputs of different fire models to the observed fire behavior and structural fire responses in the community.

Only by conducting methodical studies (field data collection, experiments and modeling) of destroyed communities that have partly or fully implemented hazard reduction principles, like Firewise, ${ }^{20}$ will we be able to assess the reliability and effectiveness of such treatments. It is critical that the guidance generated for the public should be tested and implementable. Only by offering usable and tested solutions, will we be able to reduce future WUI losses.

\subsection{Acknowledgments}

The authors would like to acknowledge the critical contributions from CALFIRE Chief Ernylee Chamlee, San Diego Fire Department Chief Tracy Jarman, and San Diego Police Department Chief William Lansdowne. Additionally, the authors would like to acknowledge Mr. Steve Arnold, President of The Trails Home Owners Association, for his critical contributions in organizing the data collection efforts with The Trails residents and Jimmy Zurenko for his data collection support. Lastly, the authors would like to thank residents of The Trails and of the city 
of Poway. Collaboration with Dr. Samuel Manzello of NIST has been an important element of this work and is gratefully acknowledged. 


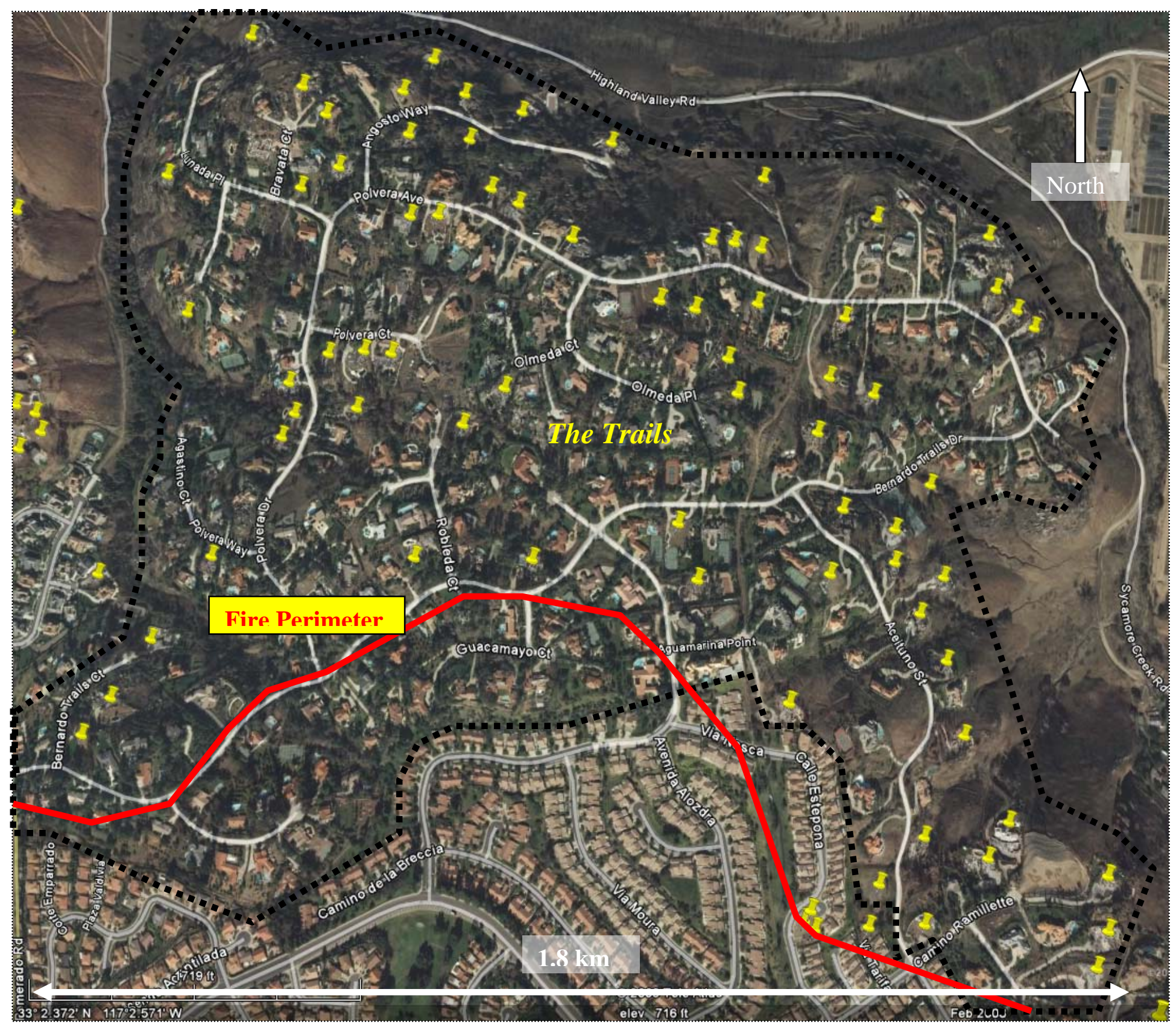

Figure 1: The Trails Community, Destroyed Homes (in Yellow) and Fire Perimeter after the Guejito and Witch Fires 


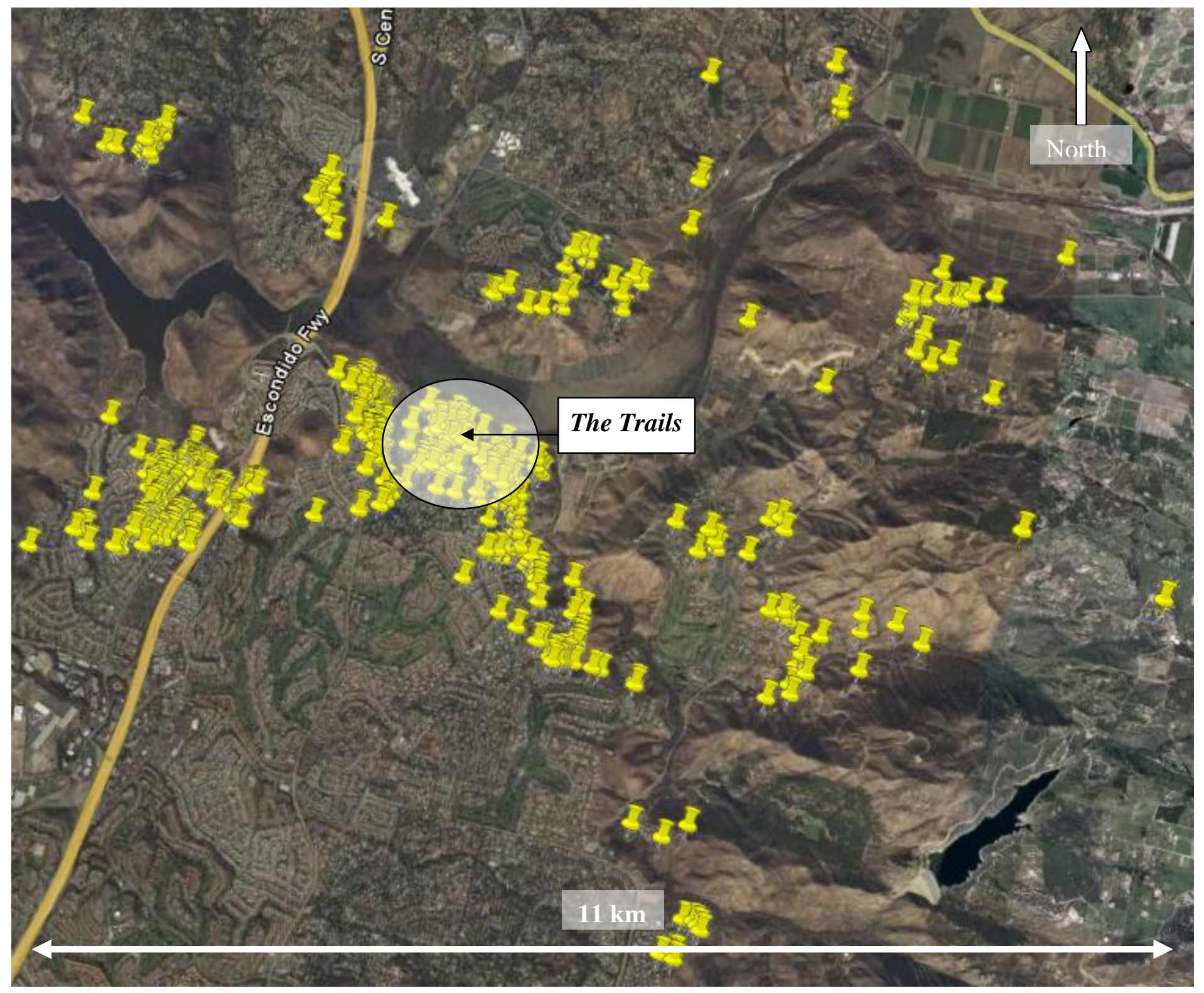

Figure 2: Destroyed Structures in the vicinity of Rancho Bernardo, CA 


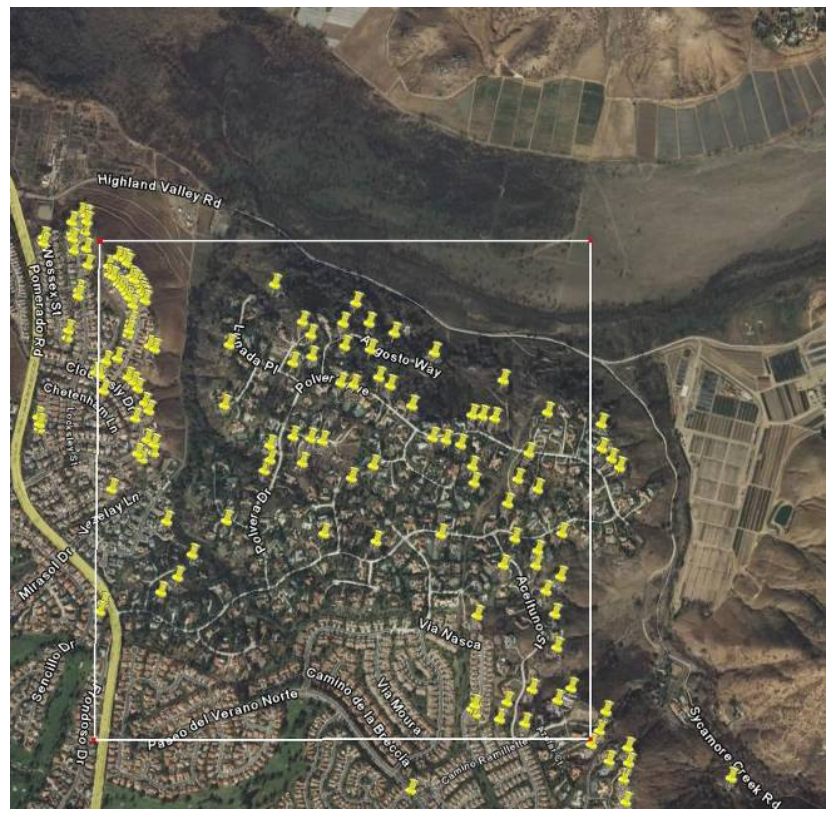

The Trails

116 homes per $\mathrm{km}^{2}$ (300 homes per square mile)

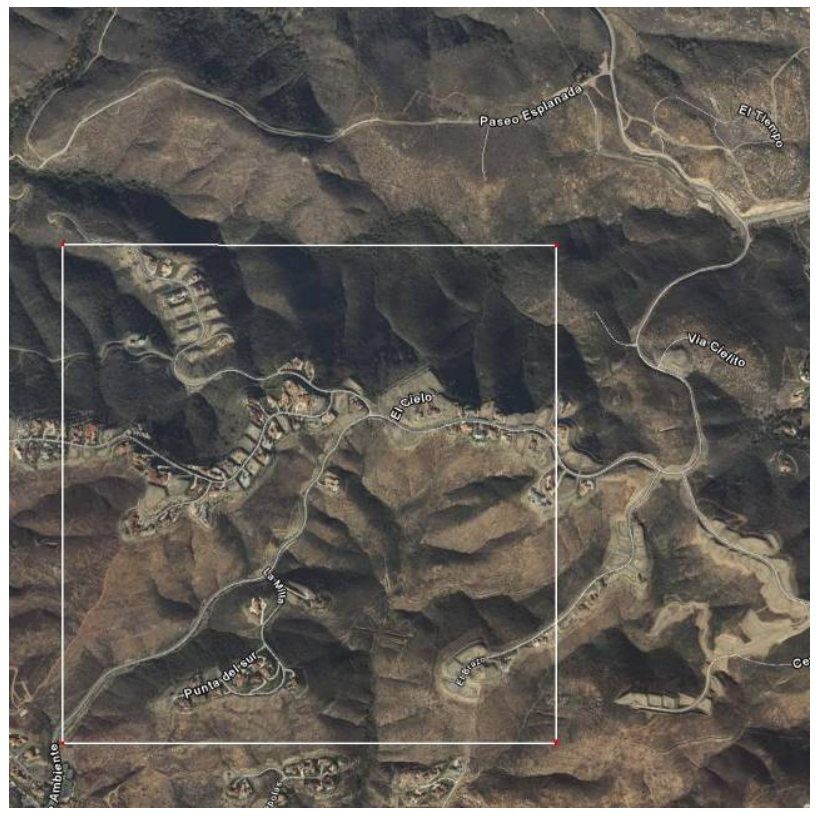

Rancho Santa Fe

31 homes per $\mathrm{km}^{2}$

(80 homes per square mile)

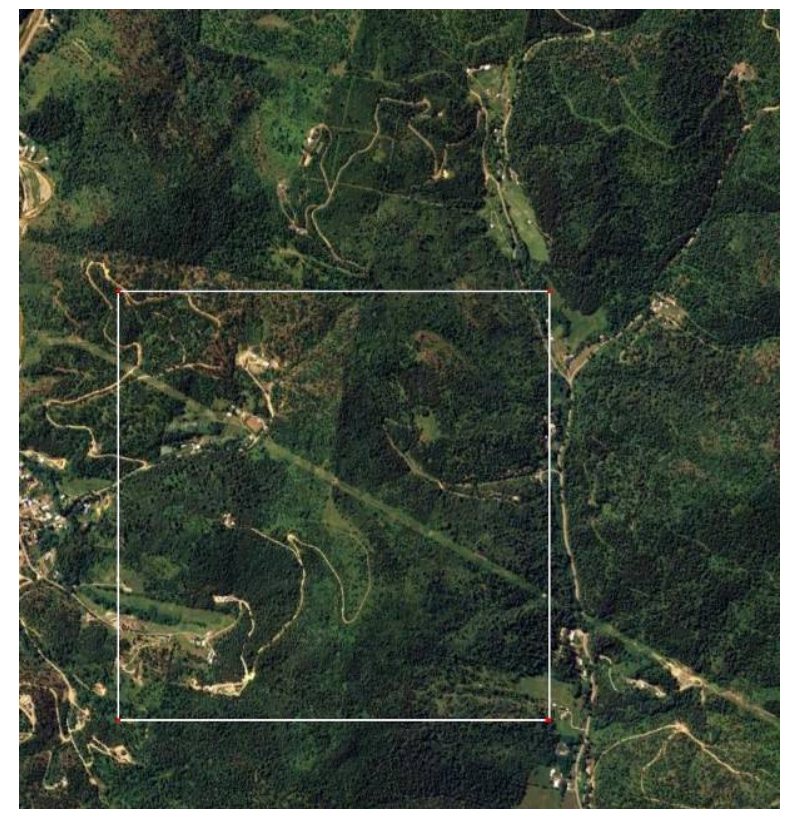

Rural Setting 4 homes per $\mathrm{km}^{2}$ (10 homes per square mile)

Figure 3: Structure Densities in Three Different WUI Settings 


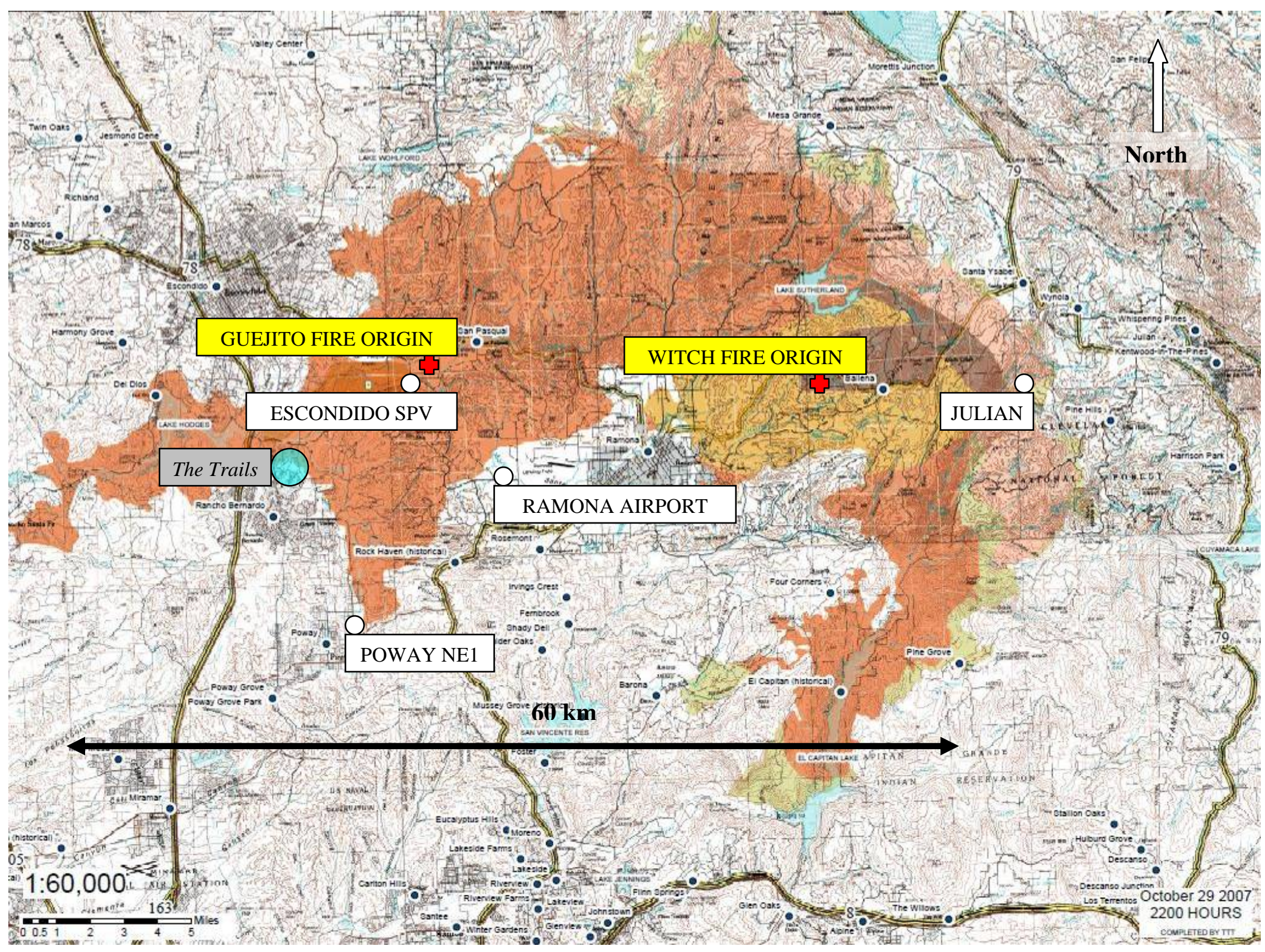

Figure 4: Origins of the Guejito and Witch Creek Fires, the combined perimeter of both fires and the locations of the weather stations used later in the report. (map Courtesy of CALFIRE) 

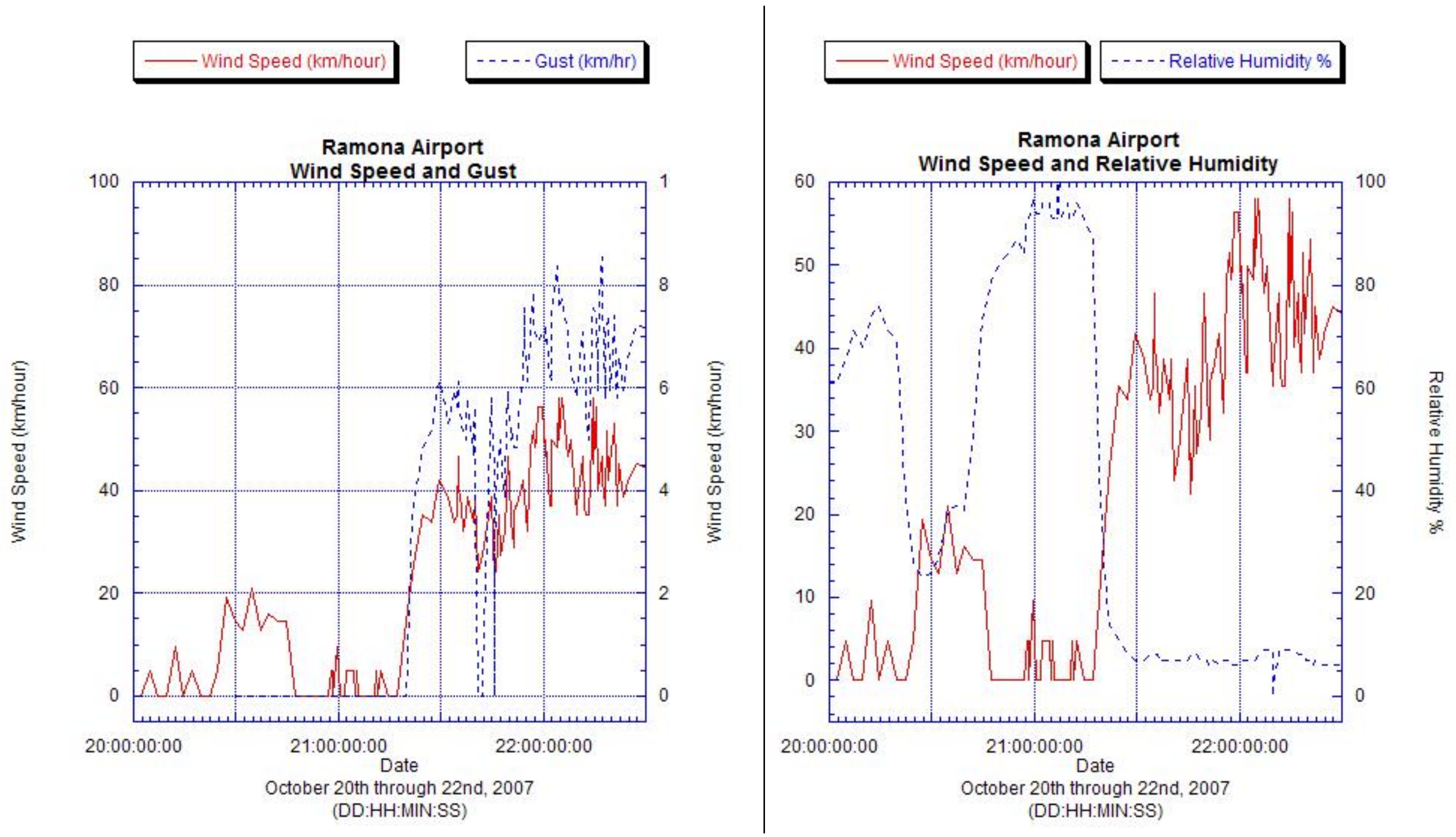

Figure 5: Weather data from Ramona Airport 


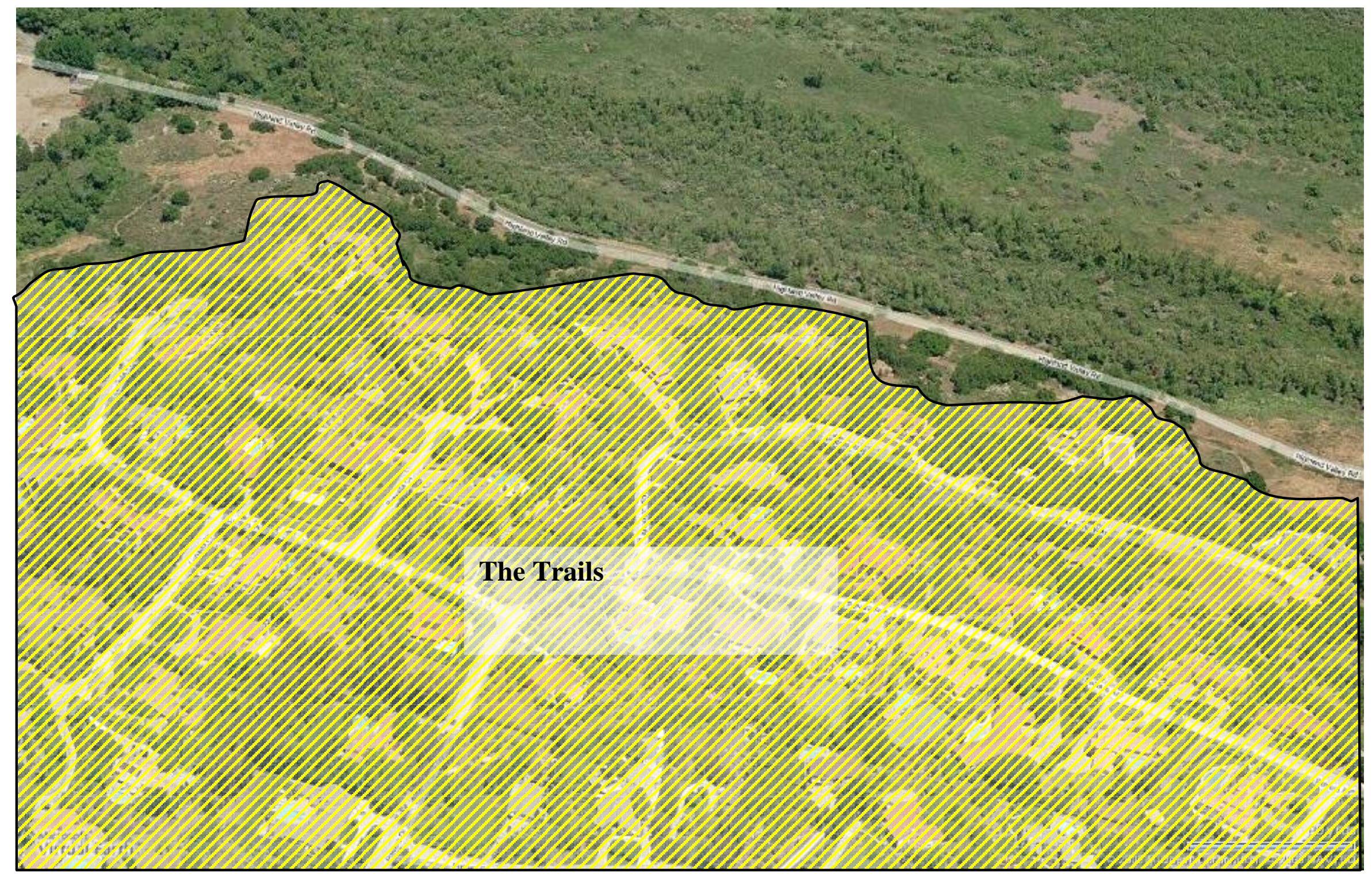

Figure 6: Northwest Corner of The Trails 


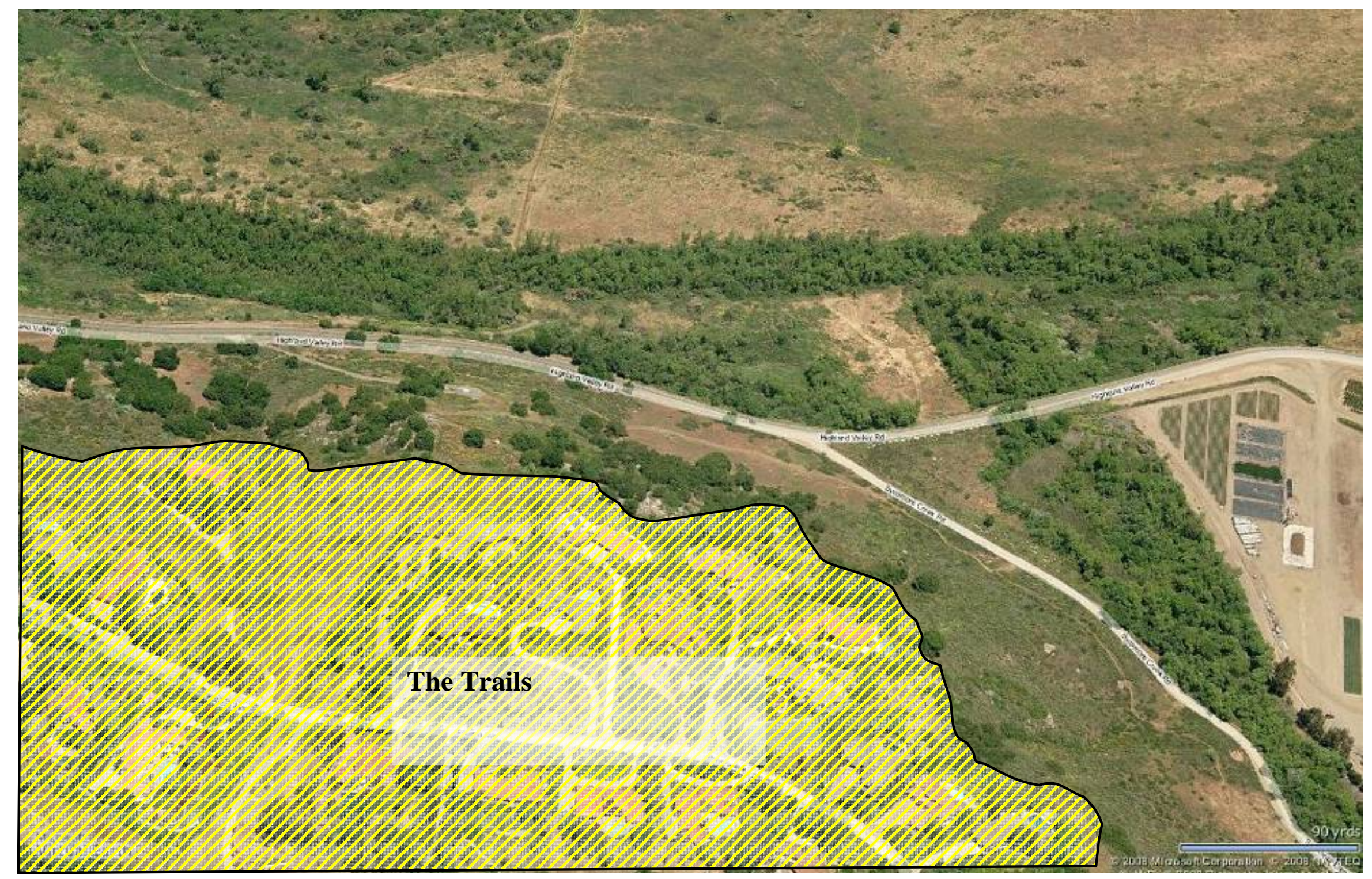

Figure 7: North Side of The Trails 


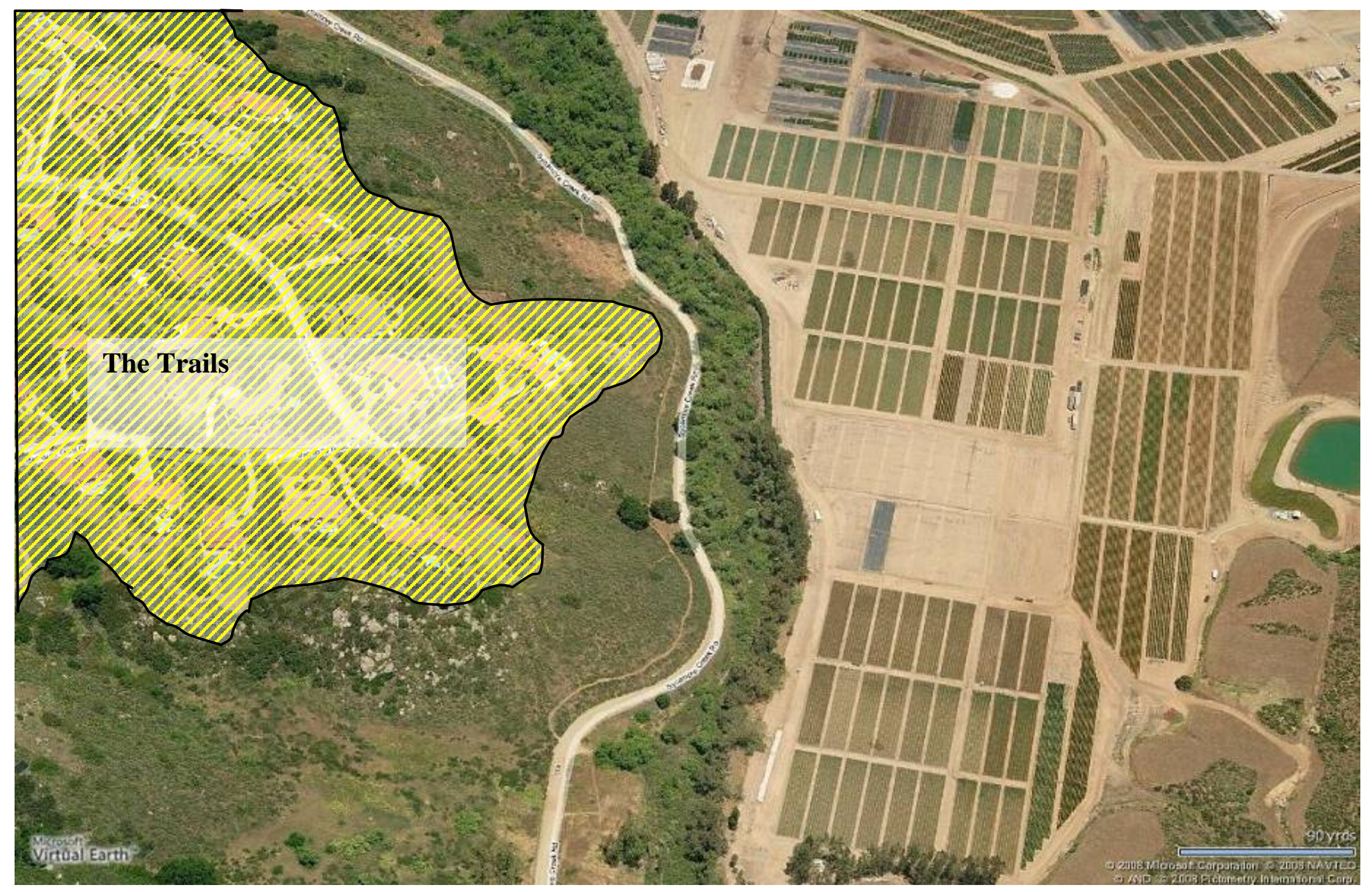

Figure 8: East Corner of The Trails 


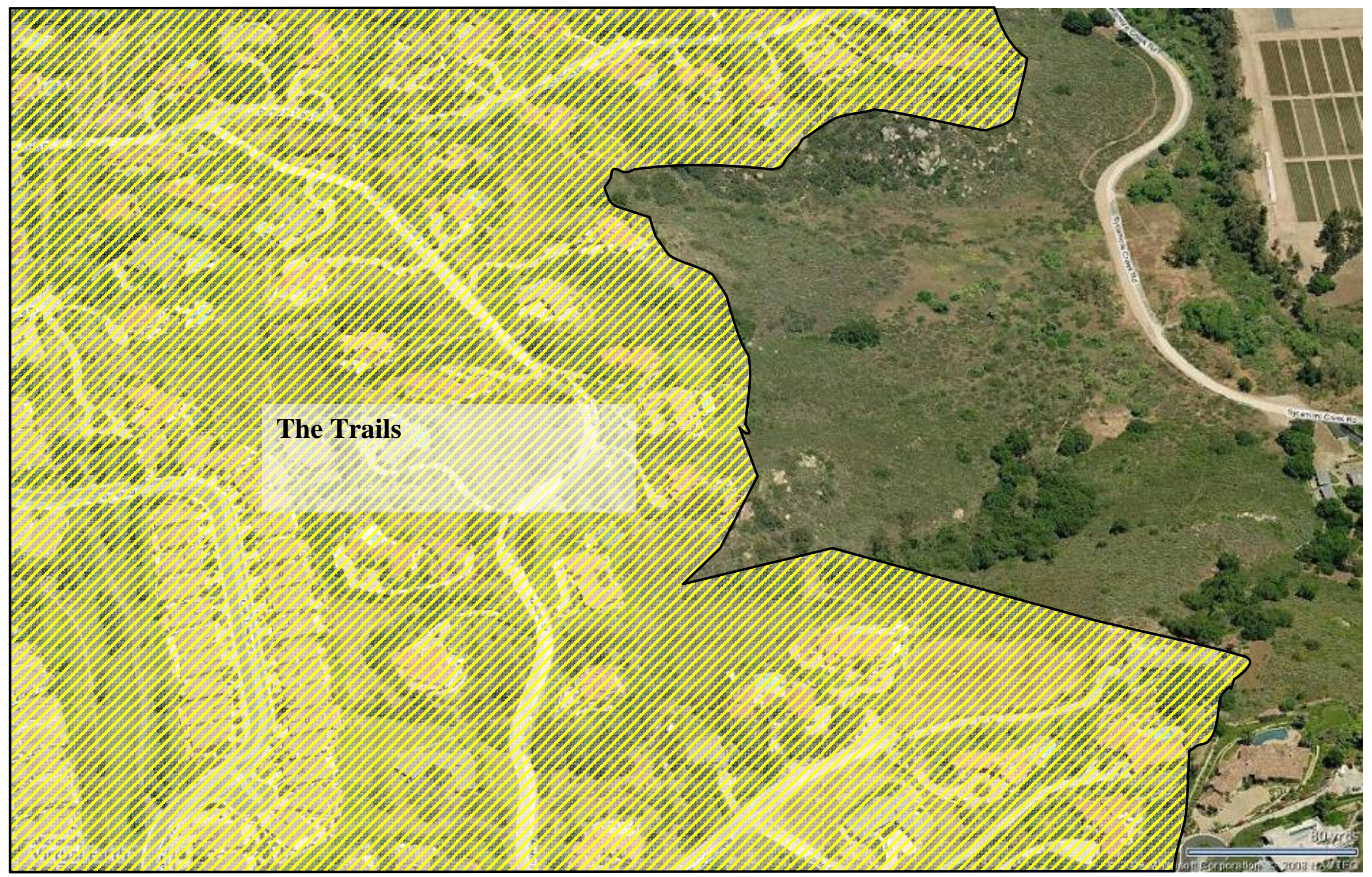

Figure 9: Southeast Corner of The Trails - Sycamore Creek 


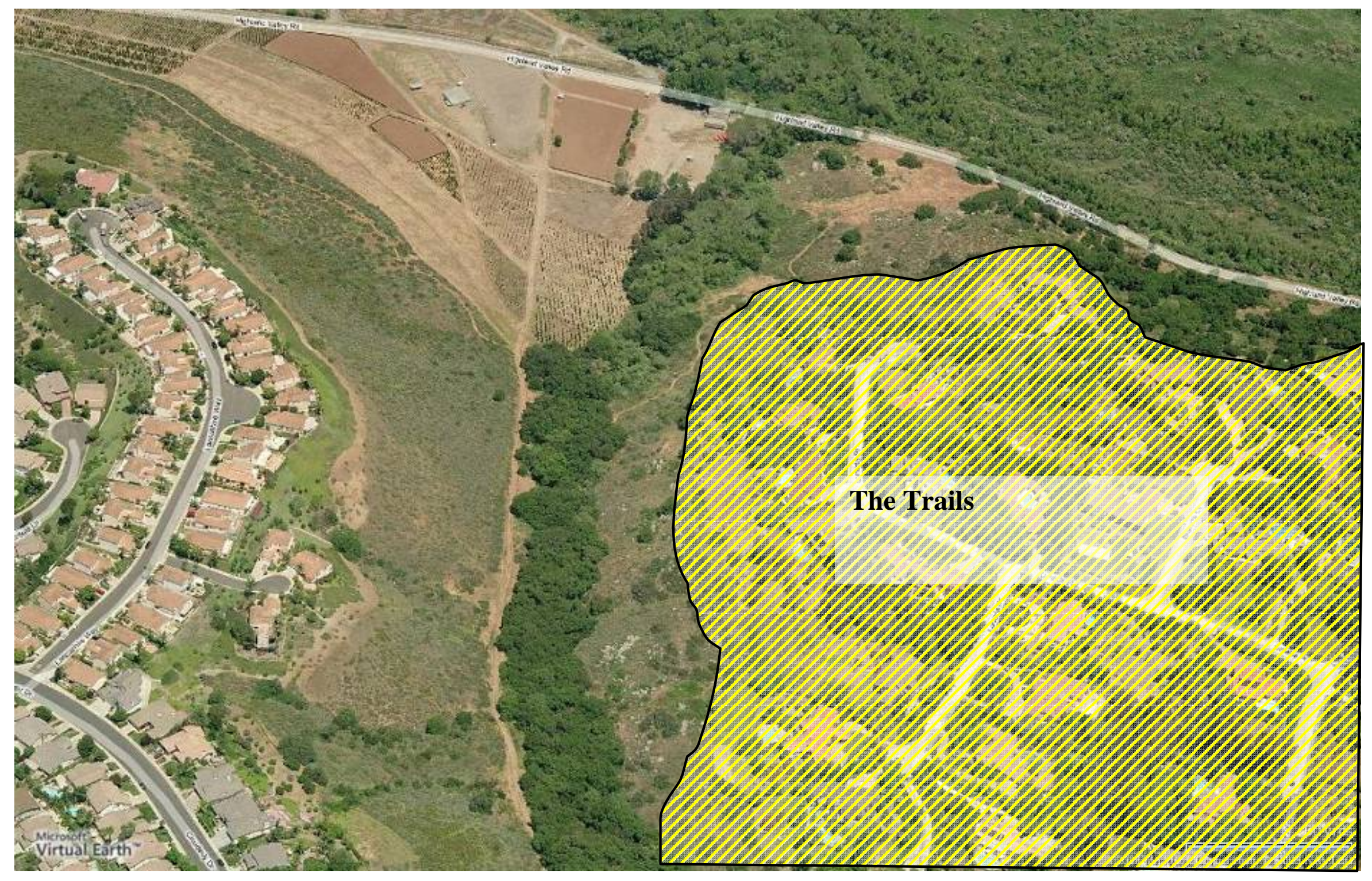

Figure 10: West side of The Trails 


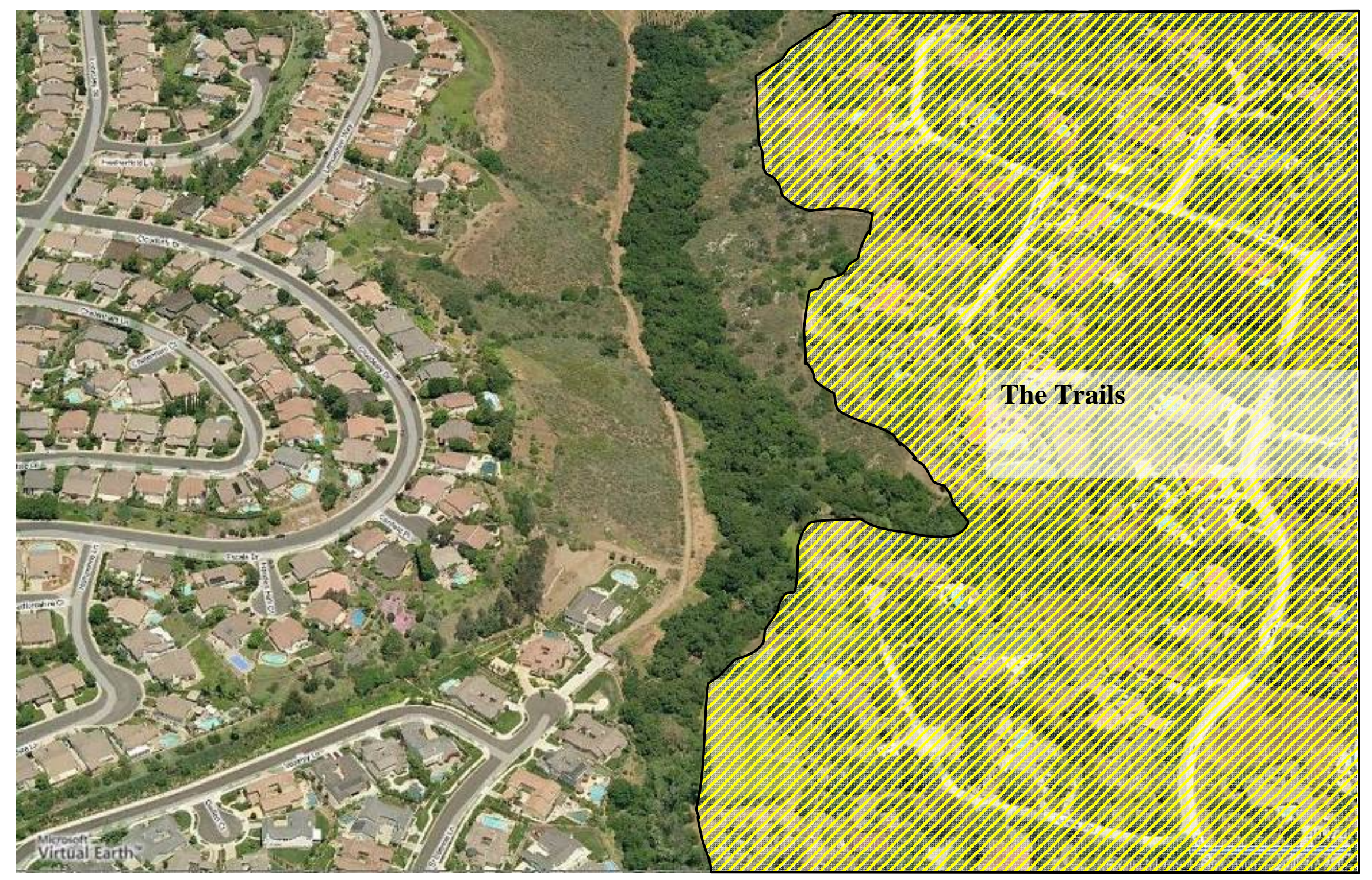

Figure 11: Southwest side of The Trails 


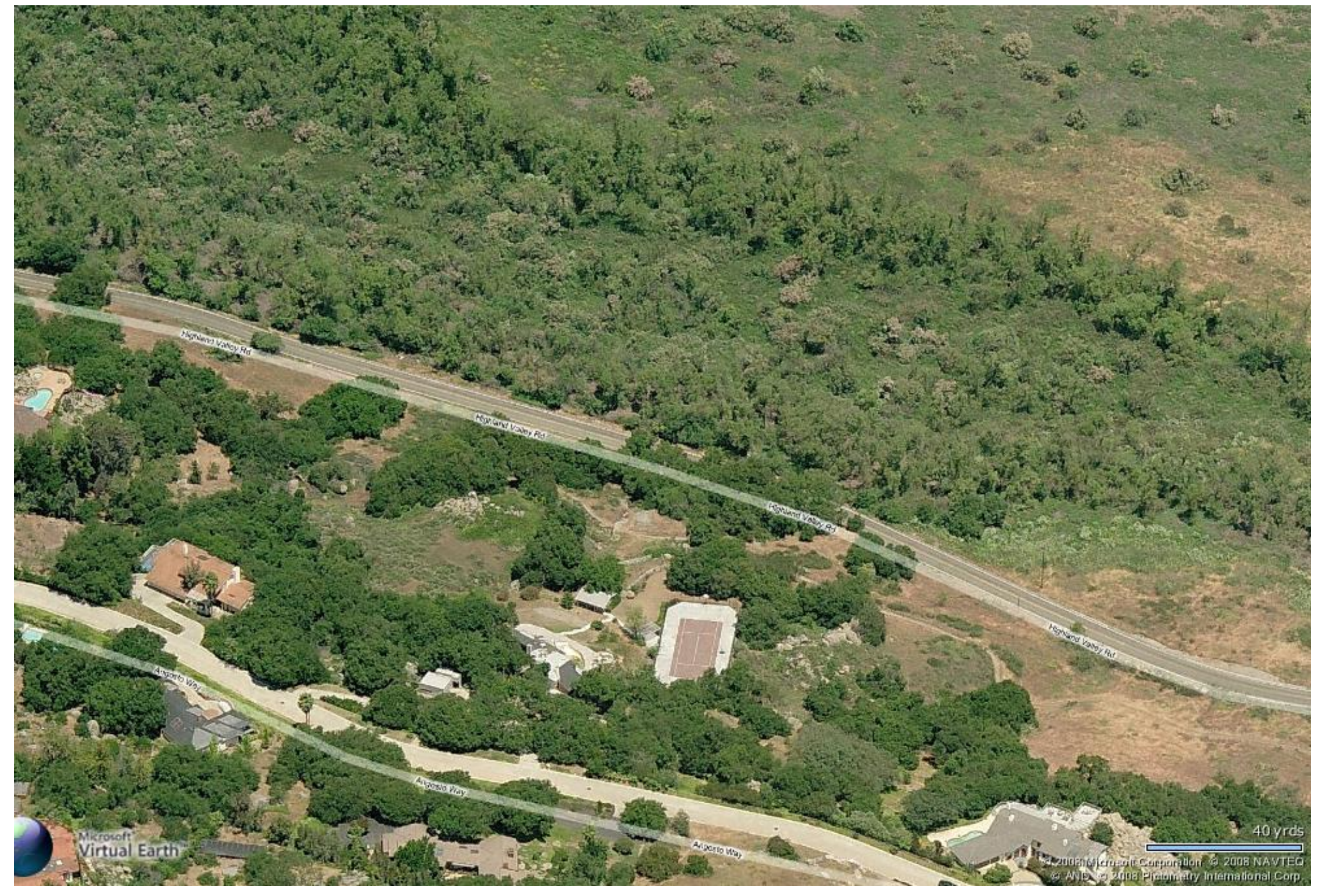

Figure 12: Angosto Way before October $22^{\text {nd }}, 2007$ (circa 2005) 


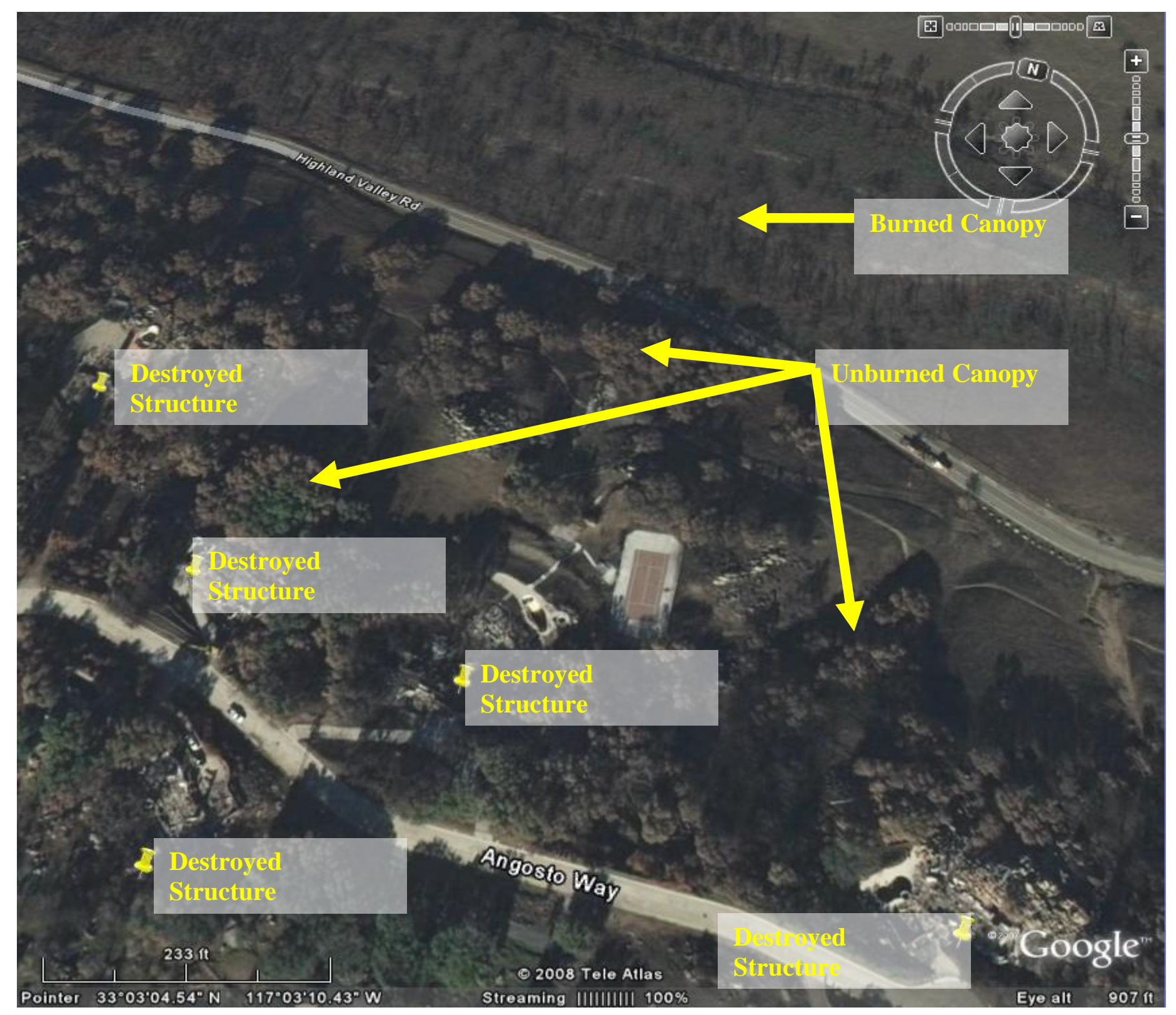

Figure 13: Angosto Way after October $22^{\text {nd }} 2007$ 


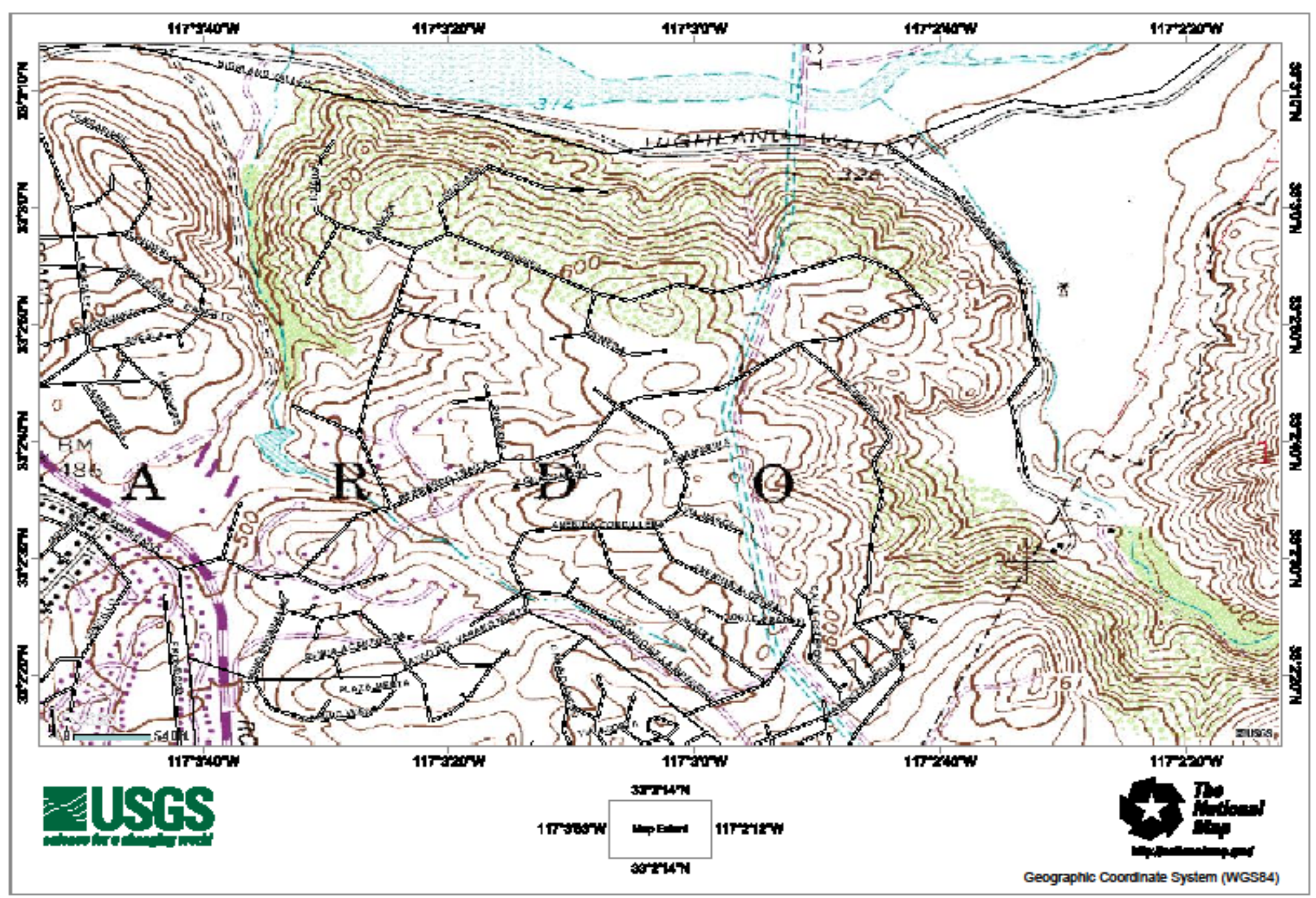

Figure 14: Topographic mps of The Trails 


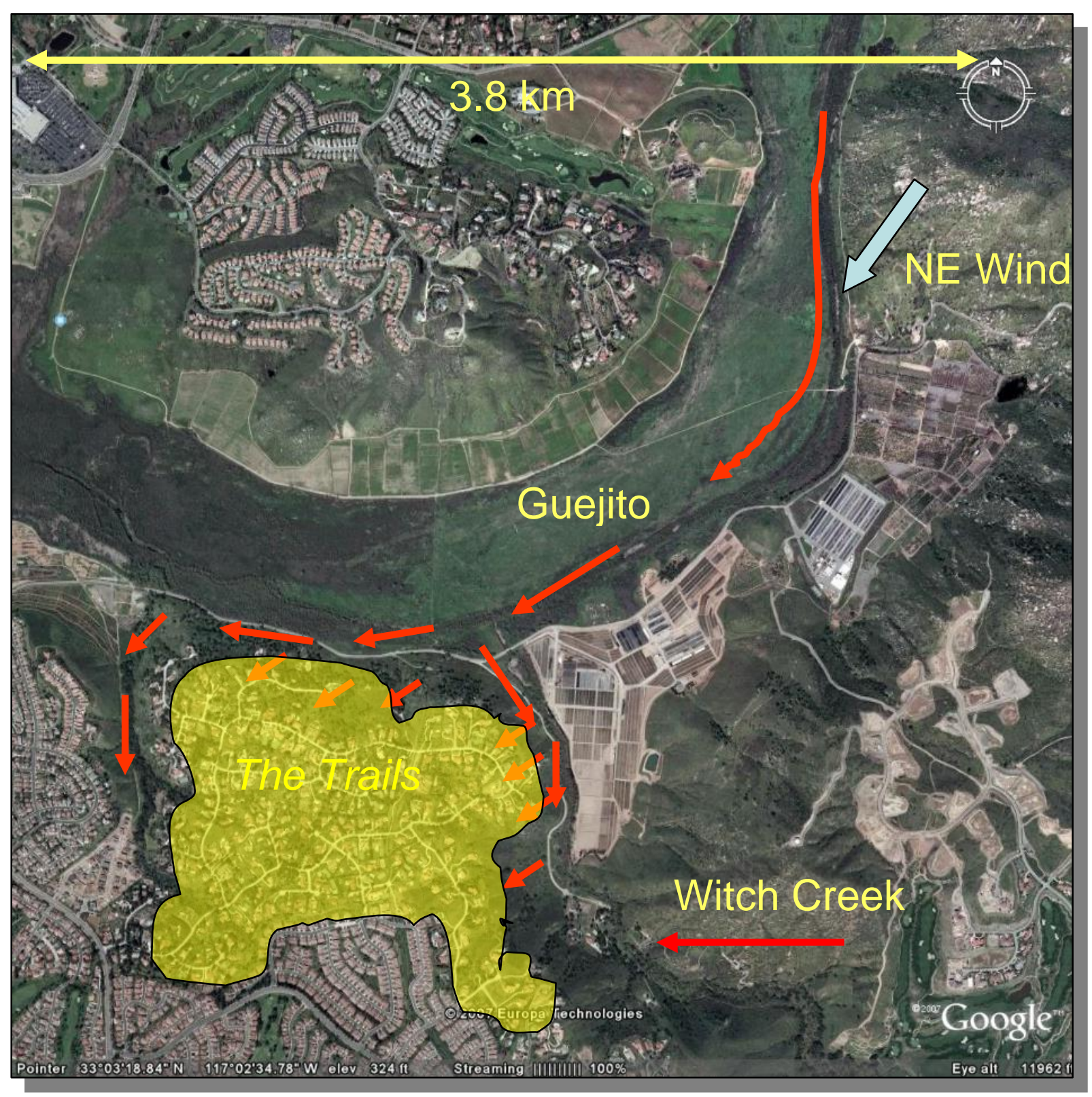

Figure 15: The Trails - Fire approach 
Figure 16: Timeline of Structures Burning in The Trails

\begin{tabular}{|c|c|c|c|c|c|c|c|c|c|c|c|c|}
\hline Time window & $2: 30$ & $3: 31$ & $4: 31$ & $5: 31$ & $6: 31$ & $7: 31$ & $8: 31$ & 9:31 & $10: 31$ & $11: 31$ & 12:31 & Total \\
\hline Ignited- some flames visible & 3 & 11 & 7 & 2 & & & & 1 & & 2 & 0 & \\
\hline Fully involved & 0 & 10 & 2 & 4 & & 2 & & & 0 & & 1 & \\
\hline Almost completely destroyed & 0 & 0 & 0 & 2 & & & & 1 & 0 & & 0 & \\
\hline New burning & 3 & 21 & 9 & 8 & 0 & 2 & 0 & 2 & 0 & 2 & 1 & \\
\hline No longer burning* & 0 & 0 & 0 & 0 & 0 & & & 1 & 0 & 4 & & \\
\hline Total & 3 & 21 & 9 & 8 & 0 & 2 & 0 & 3 & 0 & 6 & 1 & \\
\hline Cumulative Total & 3 & 24 & 33 & 41 & 41 & 43 & 43 & 46 & 46 & 52 & 53 & 53 \\
\hline Partial data* & 2 & 7 & 3 & 3 & & & & & & & & 15 \\
\hline Unknown & & & & & & & & & & & & 6 \\
\hline Grand Total & & & & & & & & & & & & 74 \\
\hline
\end{tabular}

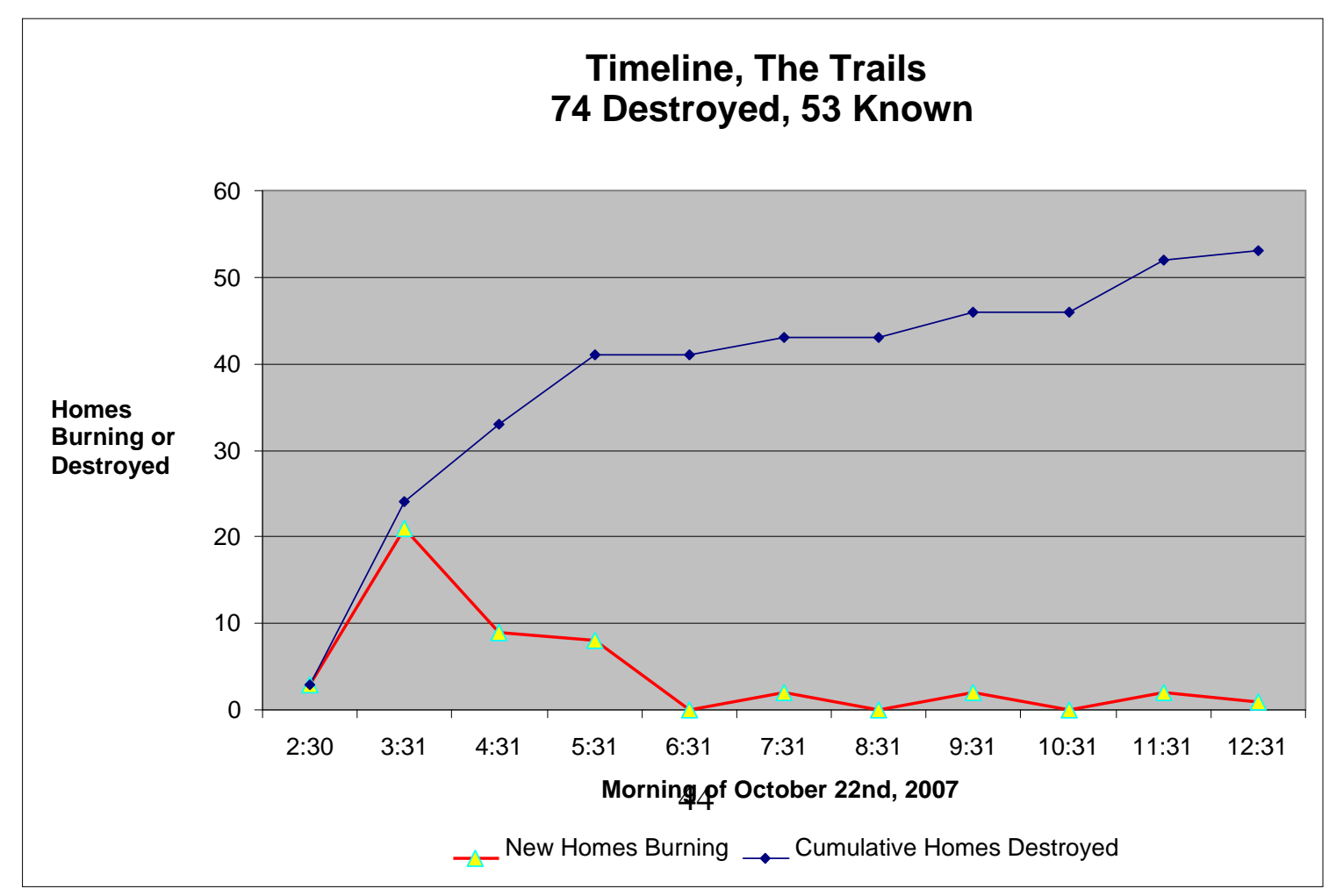


Burning

occurred

after listed

time

$2: 30-3: 55$

4:00-5:55

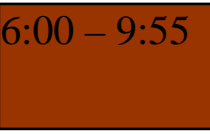

10:00 - end

All times am

unless otherwise

noted

* estimated

${ }^{1}$ 3:45 deck fires put out by SDFD,

9:30 deck fires

put out by resident

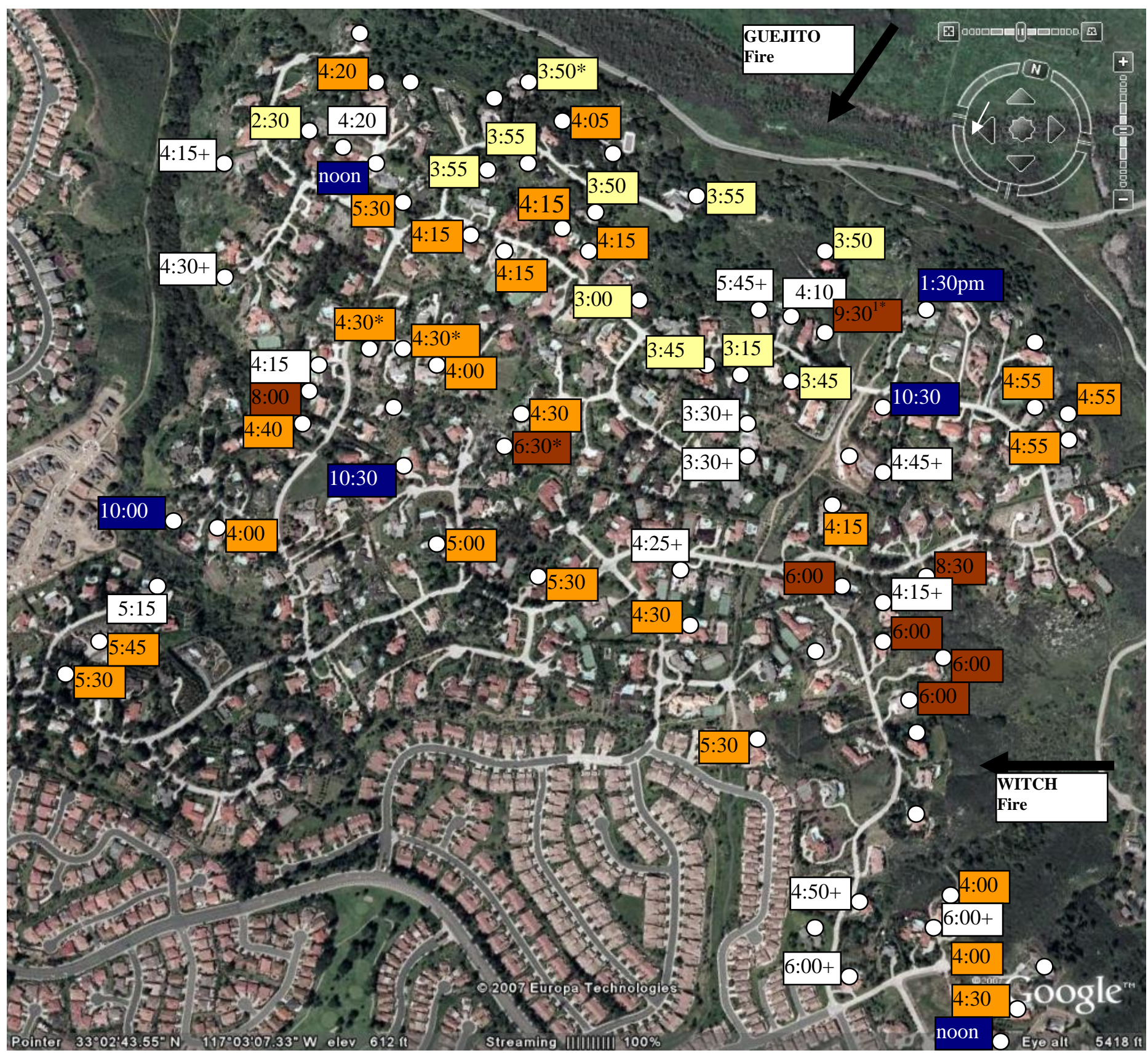

Figure 17: Timeline of structure burning at The Trails 


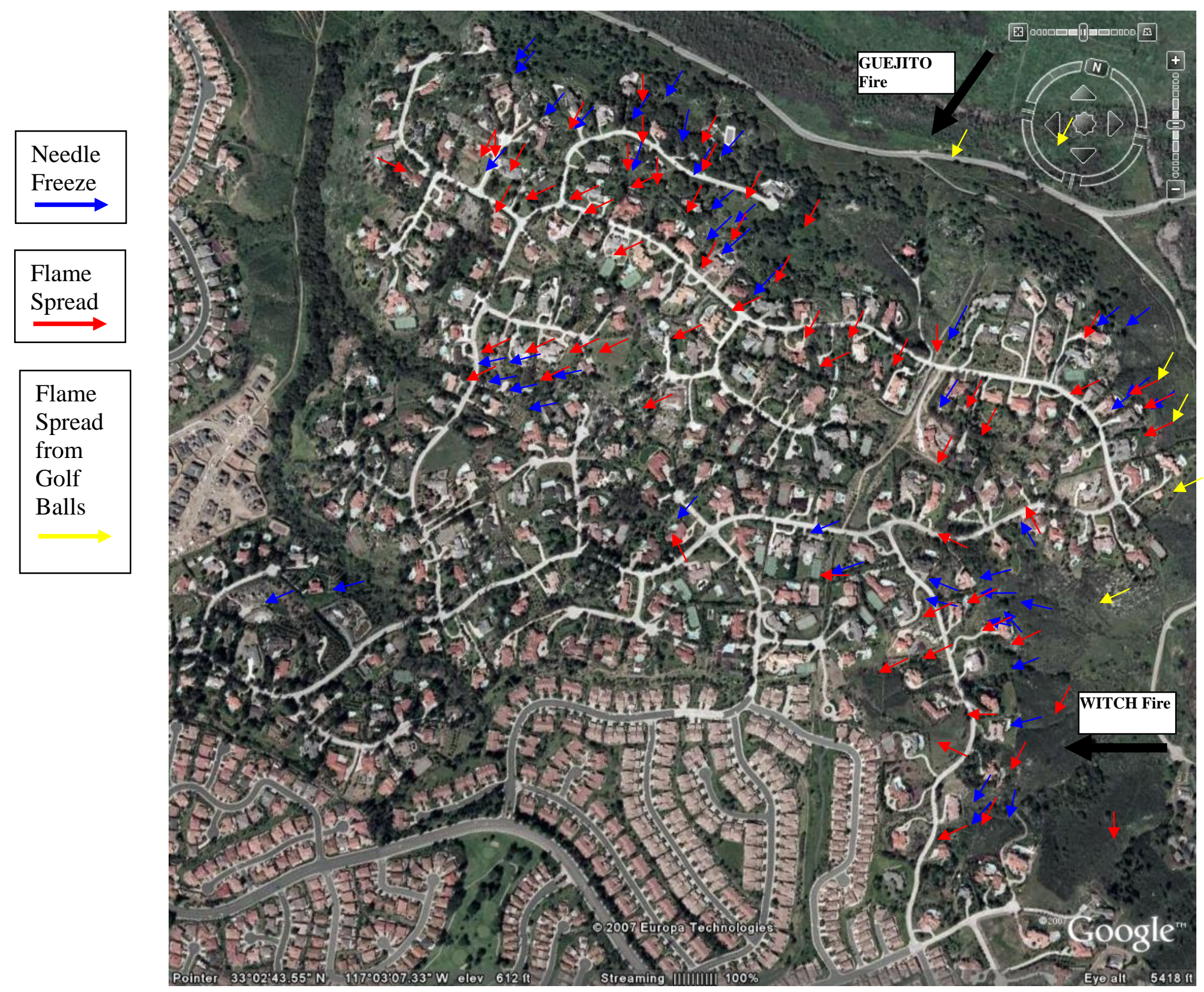

Figure 18: The Trails - Flame Spread and Needle Freeze 


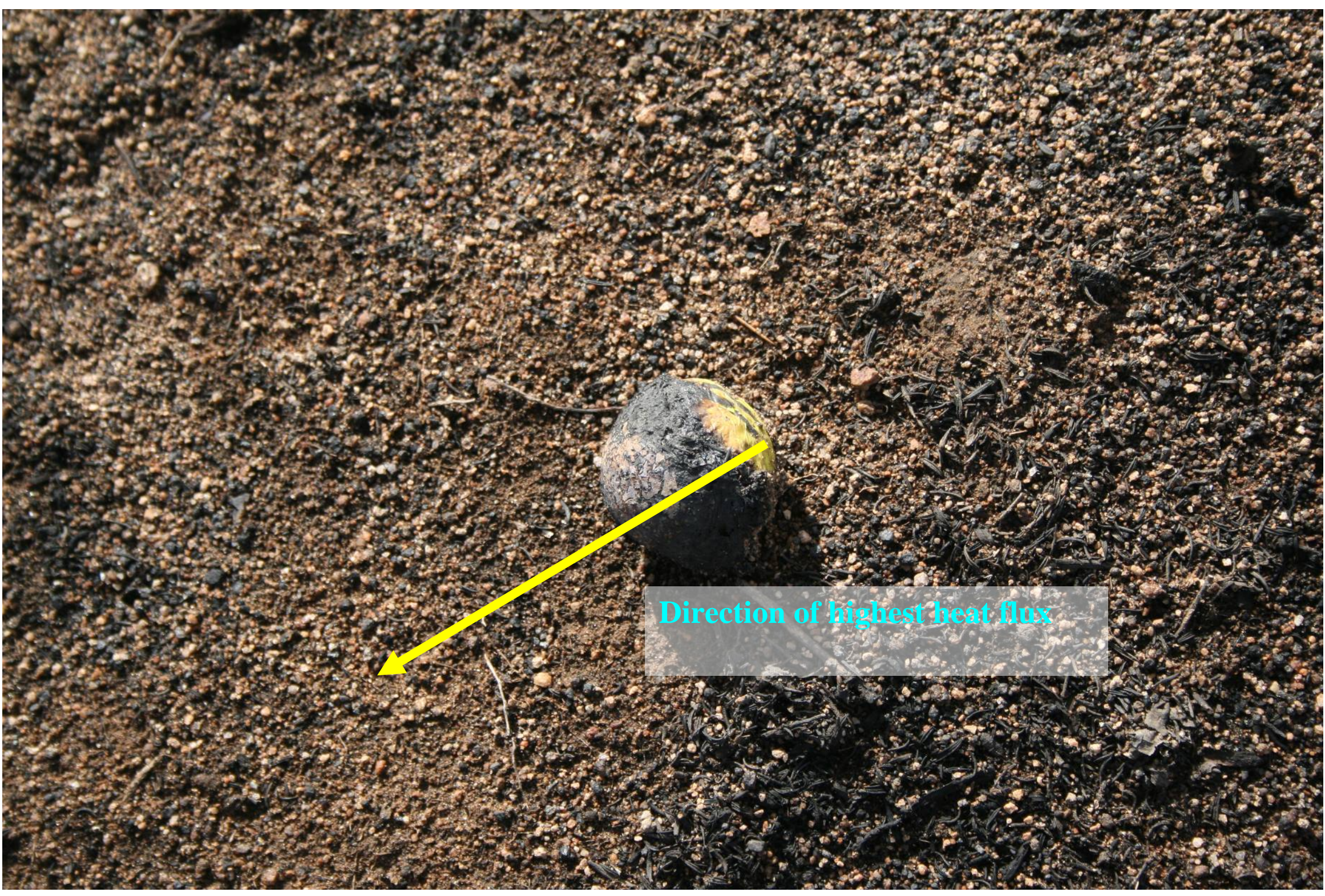

Figure 19: Golf Ball Providing Direction of Highest Heat Flux 


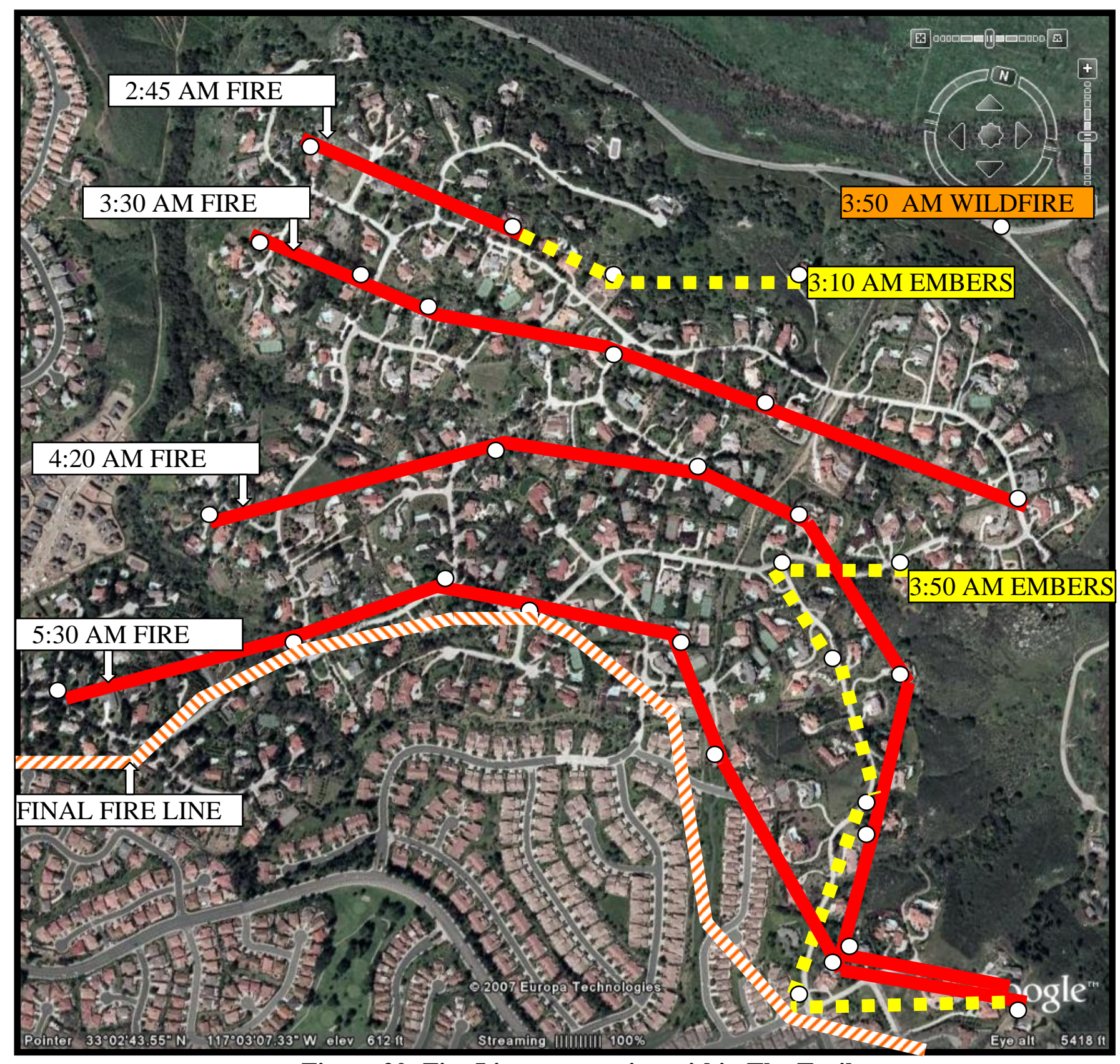

Figure 20: Fire Line progression within The Trails 


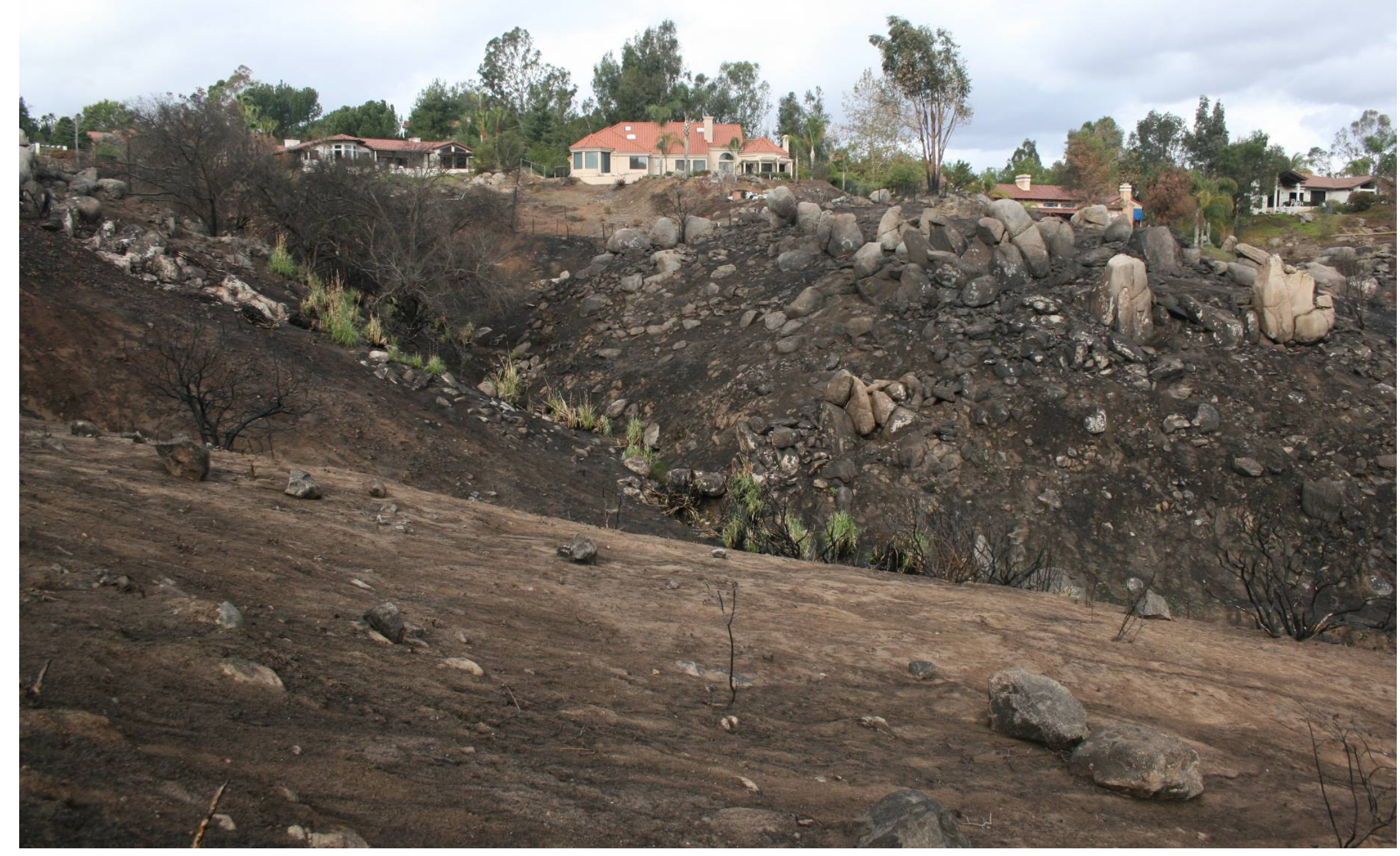

Figure 21: Rock Outcrop Acting as a Fire Break 


(85) Defensive
actions taken,
including on
21destroyed homes

$\bigcirc^{\text {(54) Destroyed }}$ home - unknown actions

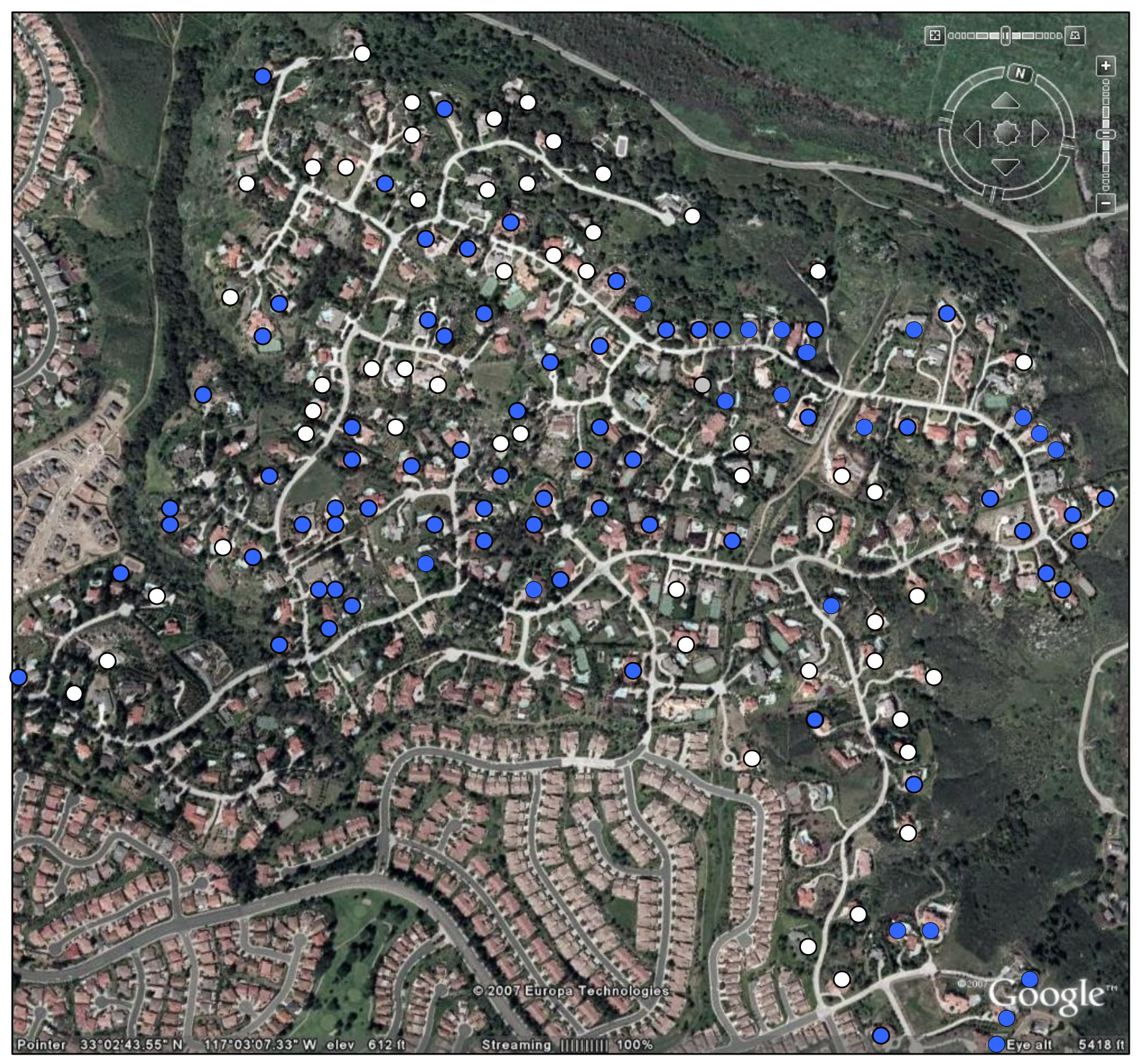

Figure 22: The Trails Defensive Actions 


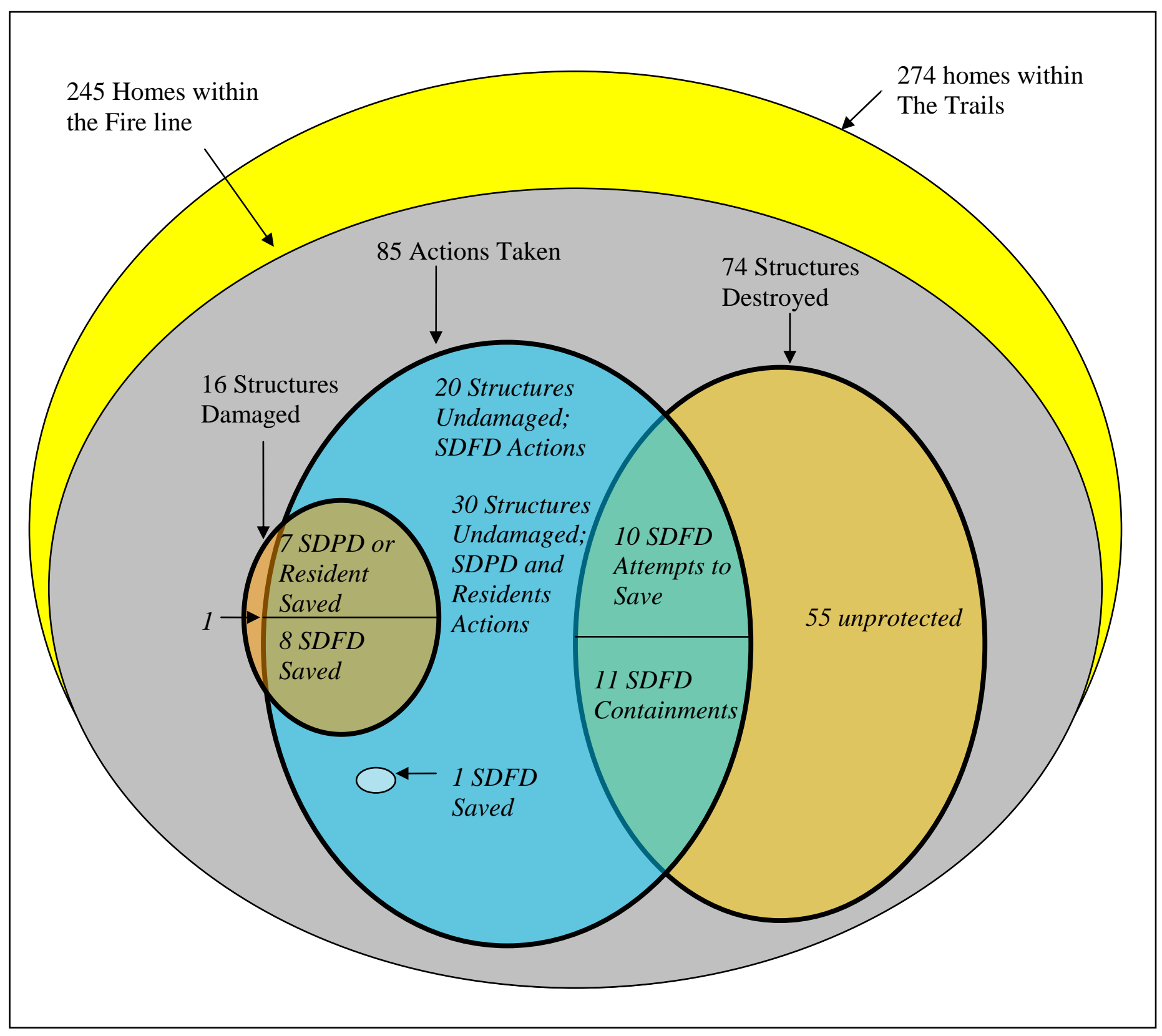

Figure 23: Impacts of the Defensive Actions Taken at The Trails 
Damaged structure -

SD FD

defensive

action taken

(8)

Damaged structure defensive action taken (7)

Damaged structure - no known action (1)

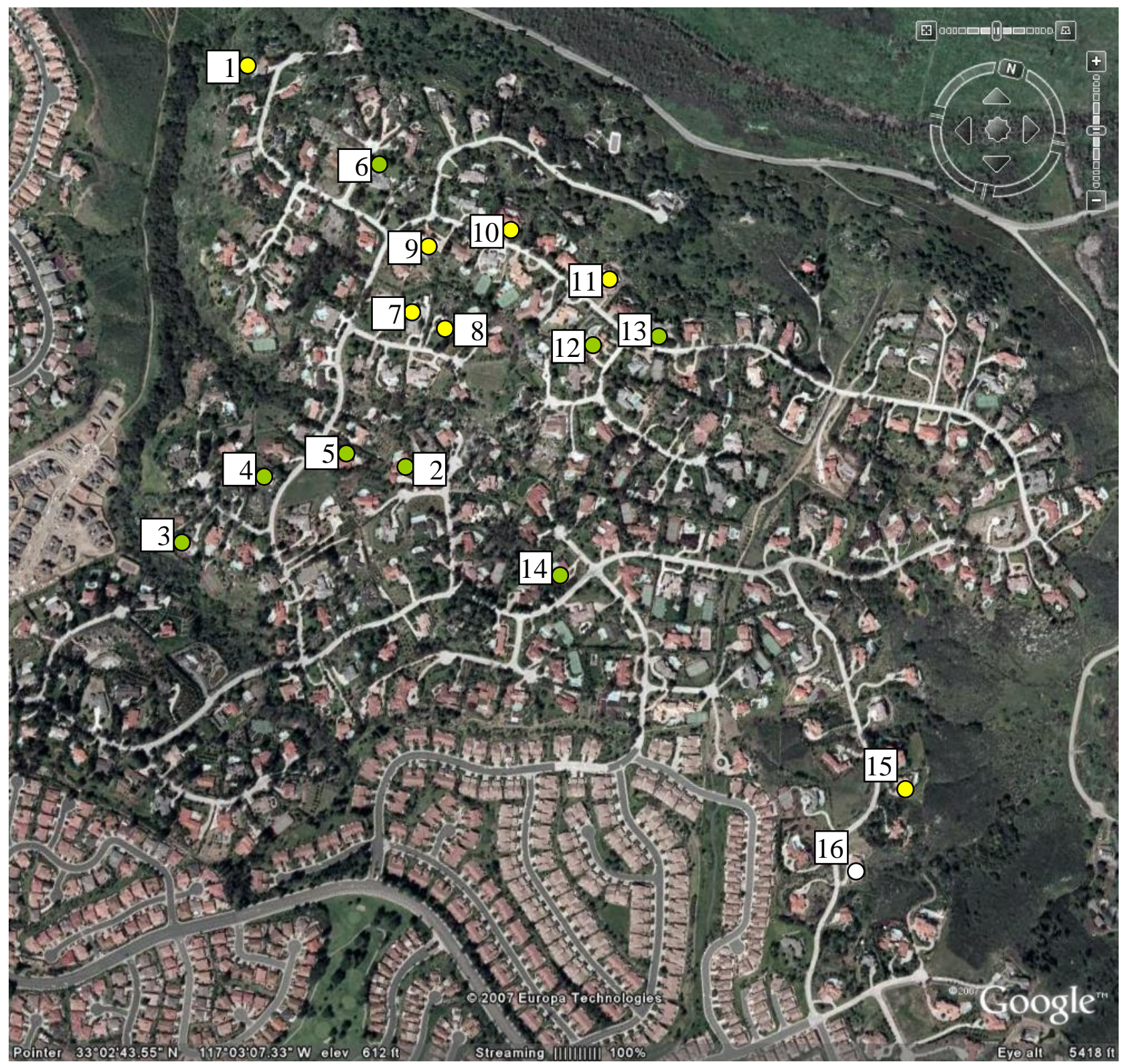

Figure 24: Damaged Structures. See Table 6 for further information on each house according to number on figure. 
○ A - Uninterrupted fire to structure

- B - Fire spotting

O C - Structure ignition from Embers

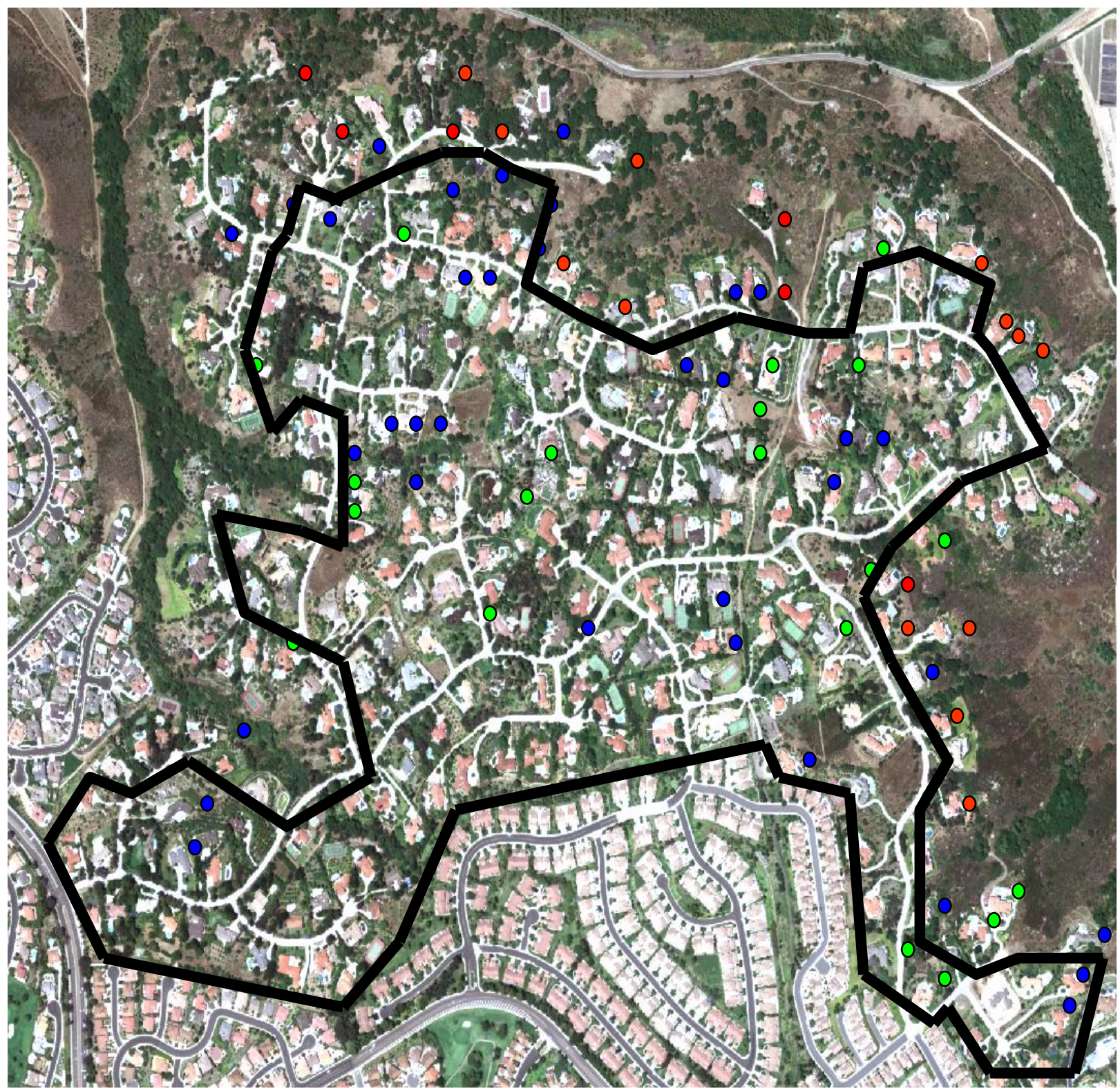

Figure 25: The Trails - Ignition categories of destroyed structures and perimeter/interior outline 


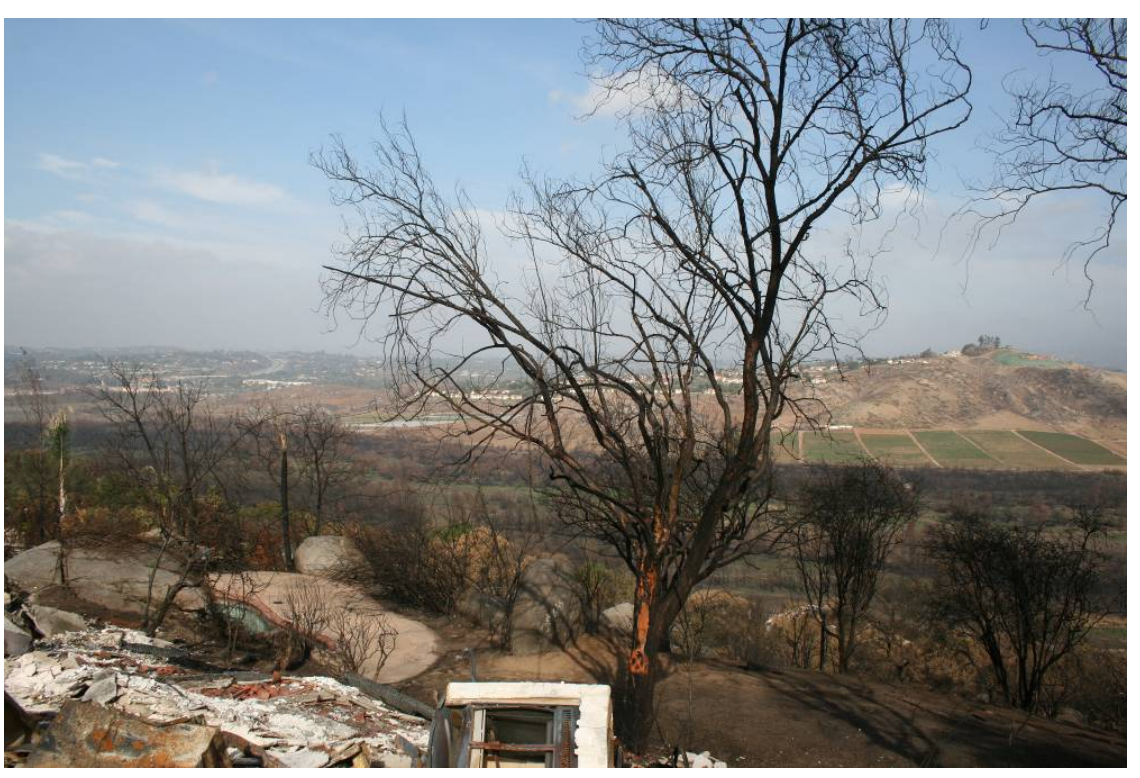

Figure 26: Structure Ignition Category A Fire from the wildlands burns uninterrupted up to the structure

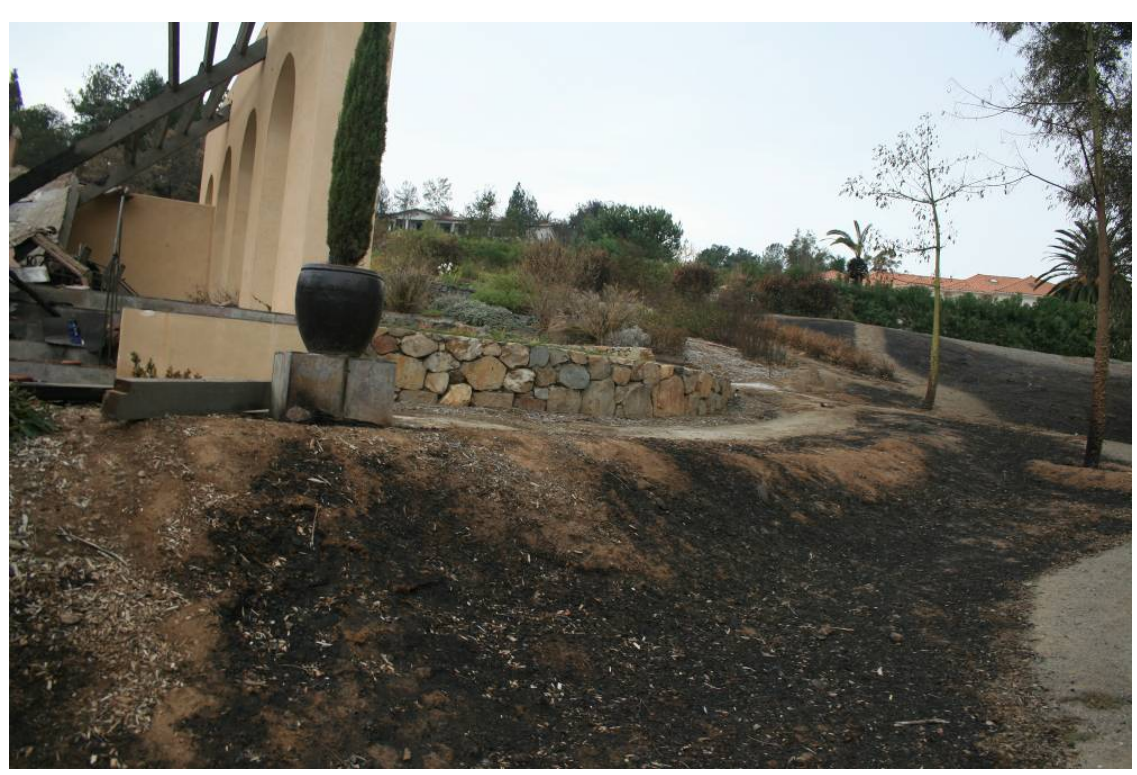

Figure 27: Structure Ignition Category B 


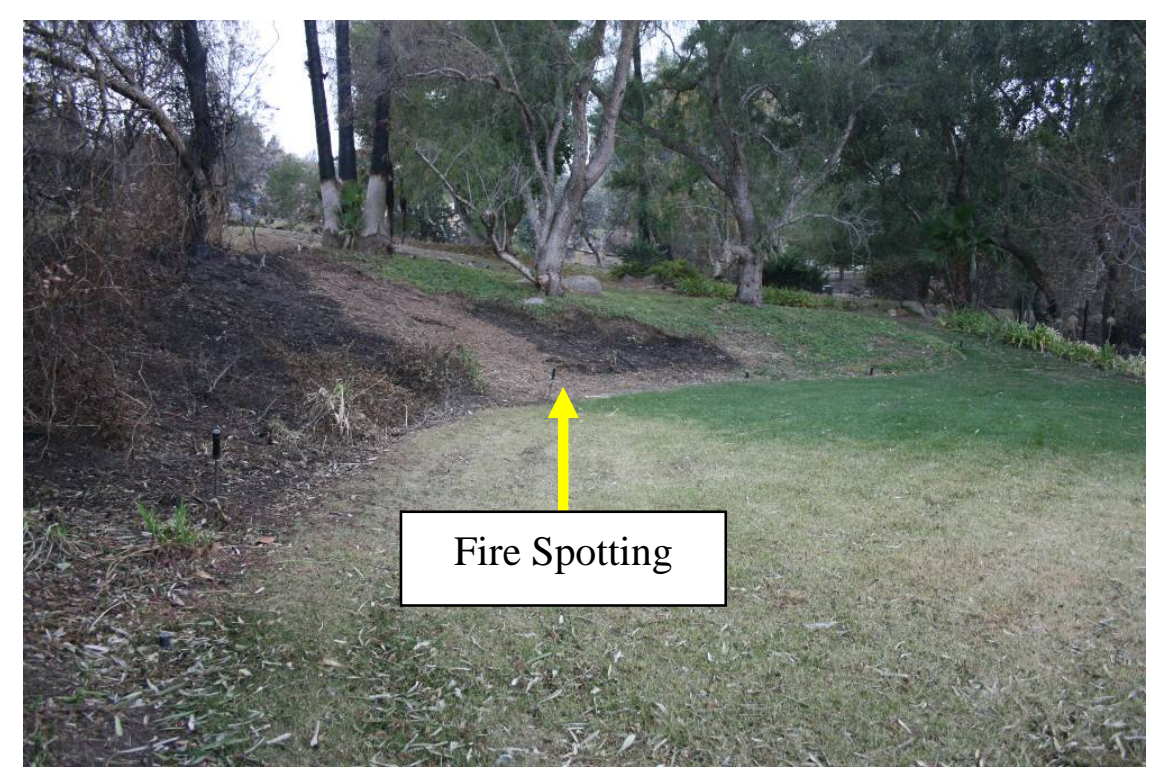

Fire spotted to vegetation next to structure and possibly onto structure

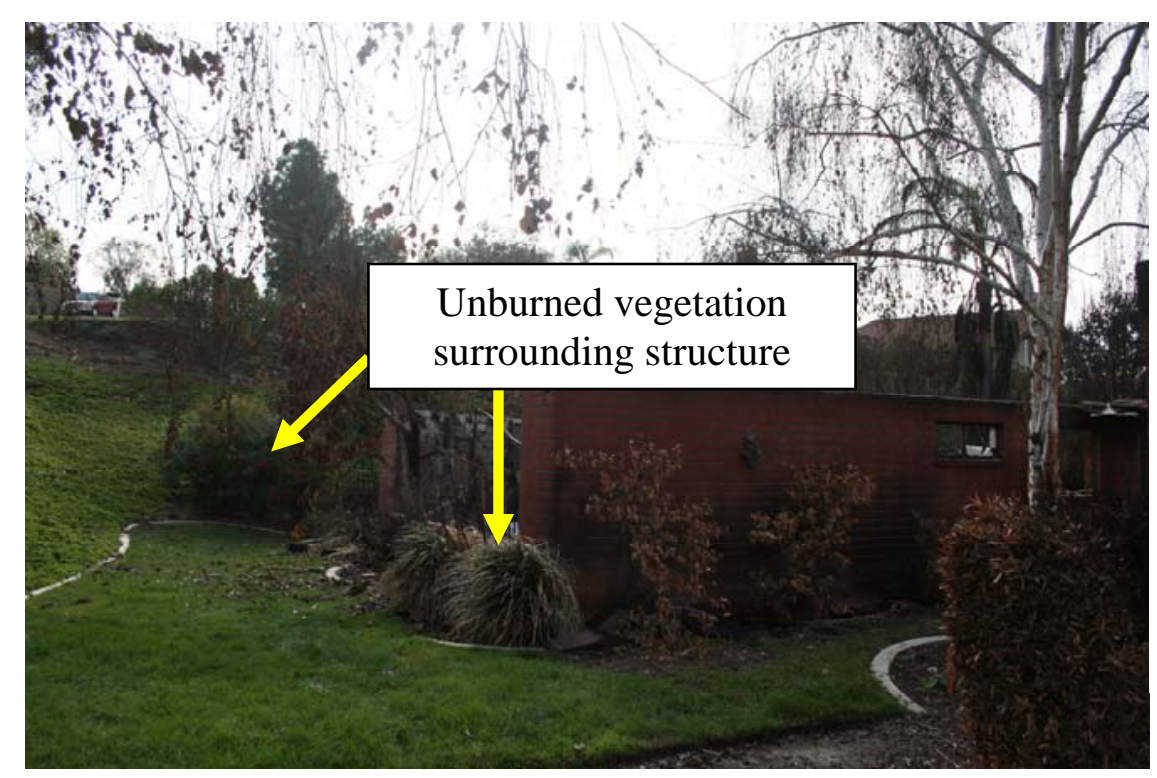

Figure 28: Structure Ignition Category C 
- A-Uninterrupted fire to structure

- B - Fire spotting

○ $\mathrm{C}$ - Structure ignition from Embers

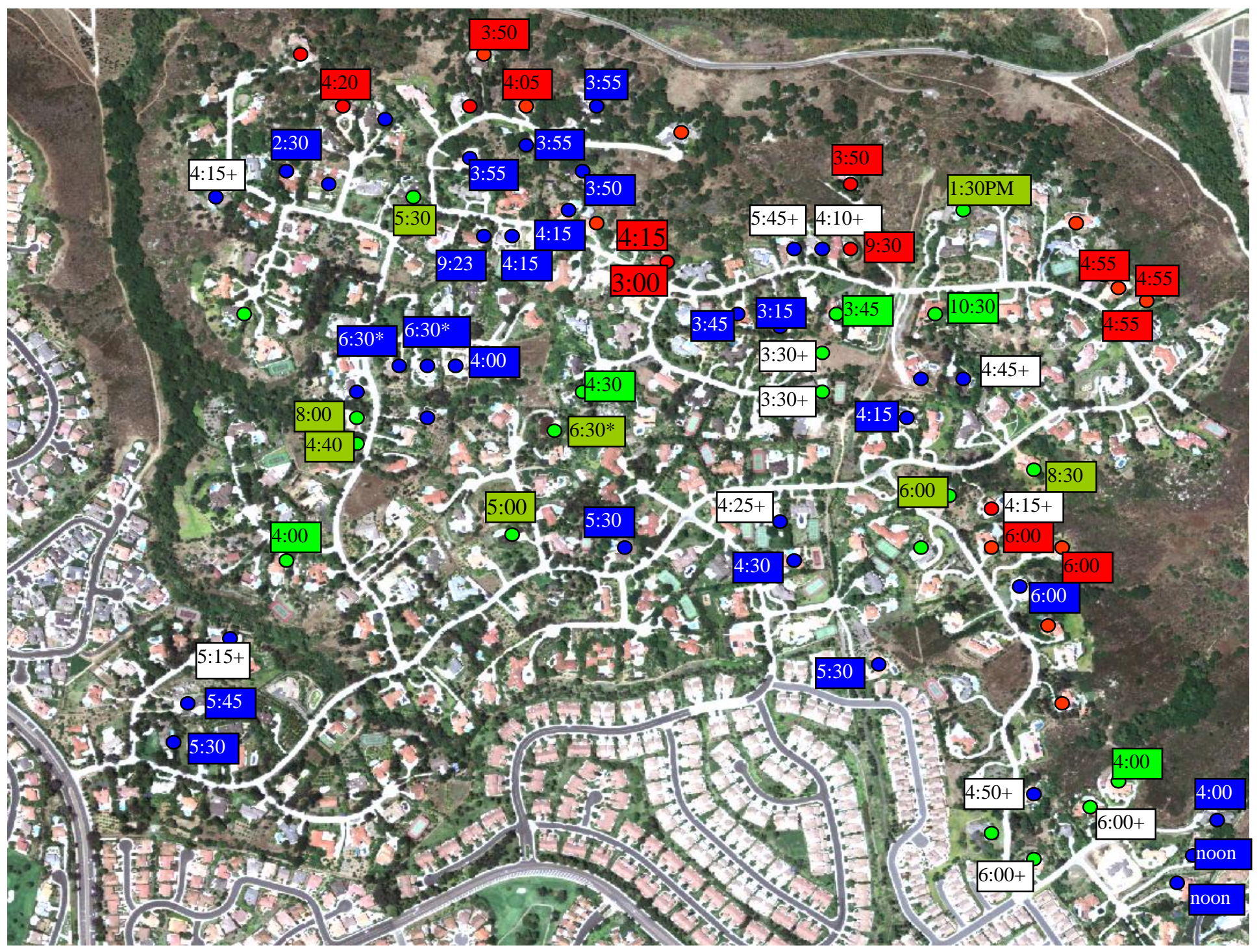

Figure 29: Potential Structure Ignition Categories A, B and C 


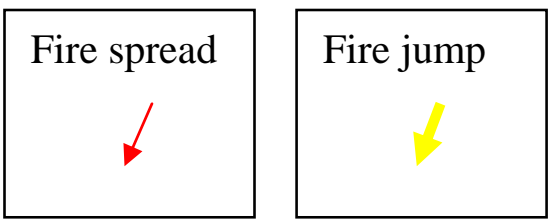

\begin{tabular}{|l|}
\hline$*$ Estimated \\
House \\
Ignition \\
\hline
\end{tabular}

House burning visible flames

House

almost gone

${ }^{1} 3: 45$ am deck fires put out by SD FD,

9:30 am

deck fires put out by

resident

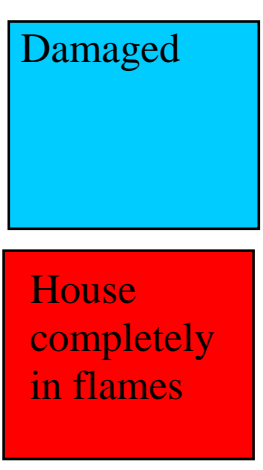

House

burned -

gone
.

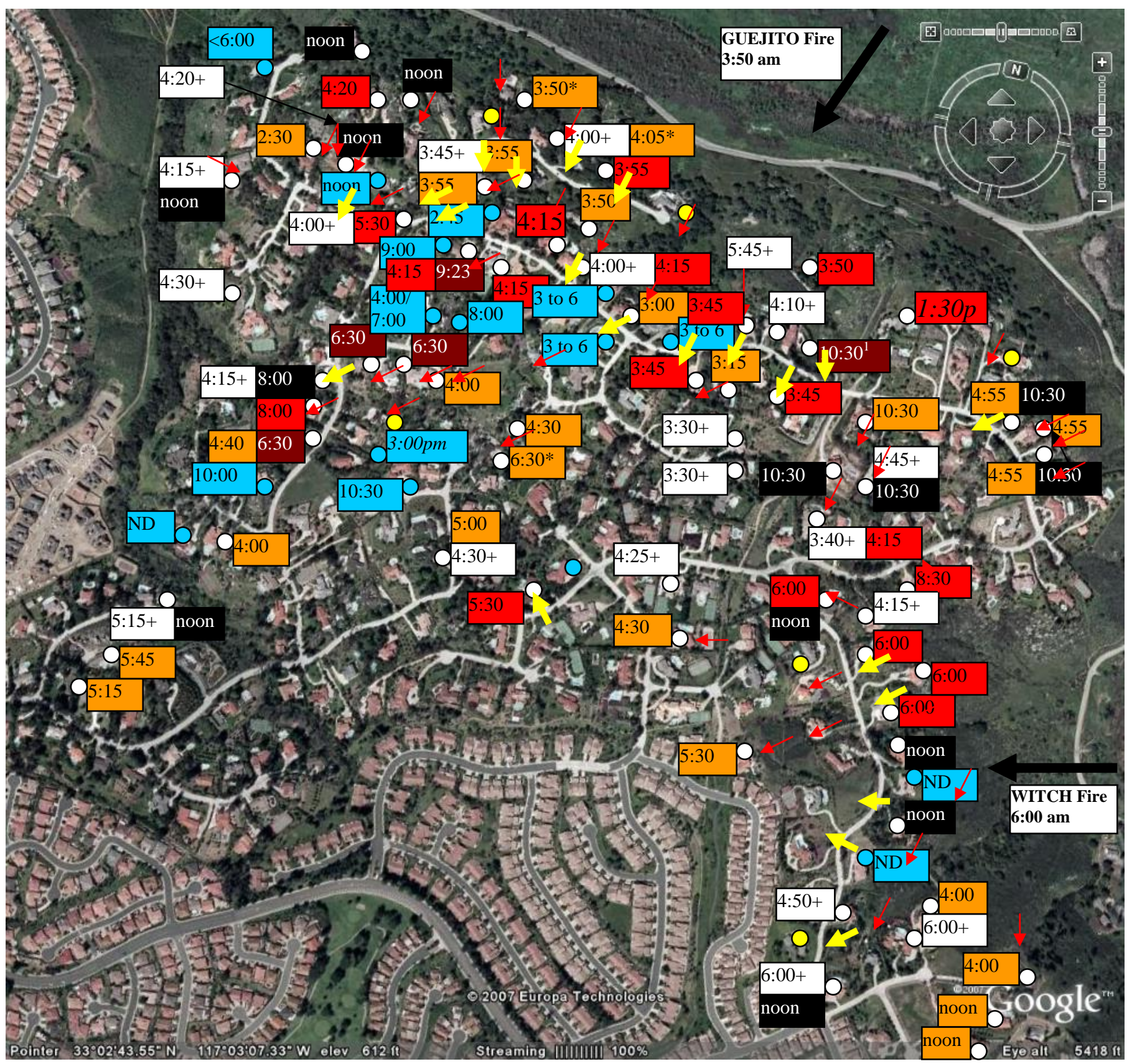

Figure 30: House burning times, fire spread and fire jumps 


\subsection{References}

${ }^{1}$ BFRL Initiates Studies of Wildland / Urban Interface (WUI) Fires, BFRL Activities, Accomplishments and Recognitions, 2004-2005, http://www.bfrl.nist.gov/Annual/20042005/BFRL06.pdf

${ }^{2}$ NFPA 1144, Standard for Reducing Structure Ignition Hazards from Wildland Fire 2008 Edition, NFPA, Quincy, MA

${ }^{3}$ The 20 Largest Califirnia Wildland Fires (By Structures Destroyed), CALFIRE Communication, January 12, 2009 http://www.fire.ca.gov/communications/downloads/fact_sheets/20LSTRUCTURES.pdf

${ }^{4}$ Michael J. Karter, Jr., NFPA Reports: U.S. Fire Loss for 2007 NFPA ,www.nfpa.org

${ }^{5}$ Mell, W.E., Maranghides, A., Manzello, S.L., Rehm, R.G., "Wildland-Urban Interface Fires: Overview and Research Needs, International J. of Wildland Fire, in review.

${ }^{6}$ Howard, Ronald A.; North, D. Warner; Offensend, Fred L.; Smart,Charles N. 1973. Decision analysis of fire protection strategy for the Santa Monica mountains: an initial assessment. Menlo Park, CA: Stanford Research Institute.

${ }^{7}$ Foote, Ethan I.D. 1996. Structural survival on the 1990 Santa Barbara "Paint" fire: A retrospective study of urban wildland interface fire hazard mitigation factors. MS thesis, University of California at Berkeley

${ }^{8}$ Kathy Murphy, Tim Rich, Tim Sexton, An assessment of Fuel Treatment effects on Fire Behavior, suppression and Structure Ignition on the Angora Fire, USDA, R5-TP-025, August 2007

${ }^{9}$ Jack D. Cohen and Richard D. Stratton, Home Destruction Examination Grass Valley Fire, Lake Arrowhead,CA, USDA, R5-TP-026b, June 2008

${ }^{10}$ Mega Fires: The Case for Mitigation, Institute for Business and Home Safety, July 2008

${ }^{11}$ Leonard JE, Blanchi R. 2005. Investigation of Bushfire Attack Mechanisms Resulting in House Loss in the ACT Bushfire 2003. A CRC Bushfire Report. Bushfire CRC Report CMIT Technical Report - 2005-478. April 2005.

${ }^{12}$ After Action Report, October 2007 Wildfires City of San Diego Response http://www.sandiego.gov/mayor/pdf/fireafteraction.pdf

${ }^{13}$ CALFIRE Investigation Report, CA-CDF-010432 (Witch Fire), http://www.fire.ca.gov/fire_protection/downloads/redsheet/CA-MVU-010432_Complete.pdf

${ }^{14}$ CALFIRE Investigation Report, CA-CDF-010484(Guejito Fire), http://www.fire.ca.gov/fire_protection/downloads/redsheet/CA-MVU-010484_Complete.pdf 
${ }^{15}$ http://www.met.utah.edu/cgi-bin/droman/mesomap.cgi?state=CA\&rawsflag=3

${ }^{16}$ Witch Incident CA MVU 010432 10/23/2007 Fuel Map, CALFIRE

${ }^{17}$ Technical communications, San Diego Fire Department, Chief Brian Fennesy, Director of Operations/ Special Operations, November 2007

${ }^{18}$ Communications with Trails residents, Mr. Steve Arnold, President, The Trails Home Owners Association, November 2007

${ }^{19}$ Glossary of Wildland Fire Terminology, PMS 205, November 2008, A publication of the National Wildfire Coordinating Group

20 www.firewise.org 